\title{
3. SITE 587: LANSDOWNE BANK, SOUTHWEST PACIFIC ${ }^{1}$
}

\author{
Shipboard Scientific Party ${ }^{2}$
}

\section{HOLE 587}

Date occupied: 3 December 1982

Date departed: 5 December 1982

Time on hole: $40 \mathrm{hr}$.

Position: $21^{\circ} 11.087^{\prime} \mathrm{S}$; $161^{\circ} 19.99^{\prime} \mathrm{E}$

Water depth (sea level; corrected m, echo-sounding): 1101

Water depth (rig floor; corrected m, echo-sounding): 1111

Bottom felt (m, drill pipe): 1115

Penetration (m): 147

Numbers of cores: 17

Total length of cored section (m): 147 (89.5 in Pliocene)

Total core recovered $(\mathbf{m}): 88.81$ ( 80.95 in Pliocene)

Core recovery (\%): 60.4 (90\% in Pliocene)

Oldest sediment cored:

Depth sub-bottom (m): 147

Nature: Calcareous sandstone

Age: Probably late Miocene

Basement: Not reached

Principal results: Site 587 is located on the southern slope of Lansdowne Bank in the southwest Pacific at $21^{\circ} \mathrm{S}, 161^{\circ} \mathrm{E}$. At this site the hydraulic piston corer penetrated $147 \mathrm{~m}$ into the upper Miocene, with good recovery only in the Pliocene. The section consists of one major lithofacies, a foraminifer-bearing nannofossil ooze to foraminifer-nannofossil ooze, interbedded with minor lithofacies of coarse-grained sediment consisting of skeletal silty sands to skeletal sandy gravels. The coarse sediment facies consists of redeposited sediments of shallow-water origin, especially corals, calcareous algae, bryozoa, and shallow-water foraminifers from the photic zone. These sediments were probably deposited during low stands of sea level.

\footnotetext{
${ }^{1}$ Kennett, J. P., von der Borch, C. C., et al., Init. Repts. DSDP, 90: Washington (U.S. Govt, Printing Office).

2 James P. Kennett (Co-Chief Scientist), Graduate School of Oceanography, University of Rhode Island, Narragansett, RI 02882; Christopher C. von der Borch (Co-Chief Scientist), School of Earth Sciences, Flinders University of South Australia, Bedford Park, South Australia 5042; Paul A. Baker, Department of Geology, Duke University, Durham, NC 27708; Charles E. Barton, Graduate School of Oceanography, University of Rhode Island, Narragansett, RI 02882 (present address: Bureau of Mineral Resources, Geology, and Geophysics, P.O. Box 378, Canberra, A.C.T., Australia); Anne Boersma, Microclimates, Inc., 404 RR1, Stony Point, NY 10980; Jean-Pierre Caulet, Laboratoire de Géologie, Muséum National d'Histoire Naturelle, 43 Rue Buffon, 75005 , Paris, France; Walter C. Dudley, Jr., Natural Sciences Division, College of Arts and Sciences, University of Hawaii at Hilo, Hilo, Hawaii 96720; James V. Gardner, Pacific-Arctic Branch of Marine Geology, U.S. Geological Survey, 345 Middlefield Rd., Menlo Park, CA 94025; D. Graham Jenkins, Department of Earth Sciences, Open University, Walton Hall, Milton Keynes, MK7 6AA, Buckinghamshire, United Kingdom; William H, Lohman, Marathon Oil Co, Denver Research Center. PO. Box 269, Littleton, $\mathrm{CO} 80160$; Erlend Martini, Geologisch-Palãontologisches Institut, Johann-Wolf gang-Goethe Universităt, Senckenberg-Anlage 32-34, D-60 public of Germany; Russell B. Merrill, Deep Sea Drilling Project A031, Scripps Institution of Oceanography, La Jolla, CA 92093 (present address: Ocean Drilling Project, Texas A\&M University, College Station, TX 77843-3469); Roger Morin, Department of Earth and Planetary Sciences, Massachusetts Institute of Technology, Cambridge, MA 02139 (present address: U.S. Geological Survey, Denver Federal Center, Denver, CO 80225); Campbell S. Nelson, Department of Earth Sciences, University of Waikato, Private Bag, Hamilton, New Zealand; Christian Robert, Laboratoire de Otologie Marine, Centre Universitaire de Luminy, Case 901,

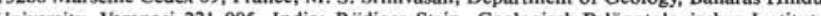
University, Varanasi 221005 , India; Rüdiger Stein, Geologisch-Palăontologisches Institut, Universität Kiel, 2300 Kiel, Federal Republic of Germany (present address: Institute of Petroleum and Organic Geochemistry (ICH-5), Kernforschungslage Jülich GmbH, P.O. Box 1913, 5170 Jülich, Federal Republic of Germany); Akira Takeuchi, Department of Earth Sciences, Faculty of Science, Toyama University, Gohuku 3190, Toyama 930, Japan.
}

Three successful in situ temperature measurements provide a linear temperature profile with depth, details of which are provided in Morin (this volume).

\section{BACKGROUND AND OBJECTIVES: LANSDOWNE BANK, SOUTHWEST PACIFIC}

Site 587 is located on the southern slope of the Lansdowne Bank (Fig. 1) which represents the most northern part of Lord Howe Rise. Lansdowne Bank lies between Lord Howe Basin to the west and New Caledonia Basin to the east. The bank rises to a present-day water depth of only $100 \mathrm{~m}$ and the crest lies within the photic zone (Launay et al., 1977; Ravenne et al., 1977).

Site 587 was selected in order to obtain an uncomplicated, high-resolution calcium carbonate sedimentary record of Neogene and late Paleogene age in an area between the warm subtropics and the equator. This location was chosen because it lies close to the edge of the true tropics at $21^{\circ} \mathrm{S}$, is in shallow depths $(1100 \mathrm{~m})$ to guarantee a calcareous pelagic sedimentary section and should provide an apparently uncomplicated stratigraphic sequence with no major terrigenous sedimentary input. However, during the selection process for Site 587, it was discovered that few shallow-water features exist at about $20^{\circ} \mathrm{S}$ in the southwest Pacific that might provide the kind of sequence of interest. The flanks of Lansdowne Bank exhibit a source of high-amplitude reflections in the upper part (0.4 s) of the section (Fig. 2) which, it was thought, might represent calcareous sediments transported from the shallow waters at the crest of the bank. Because of this, the site was considered to

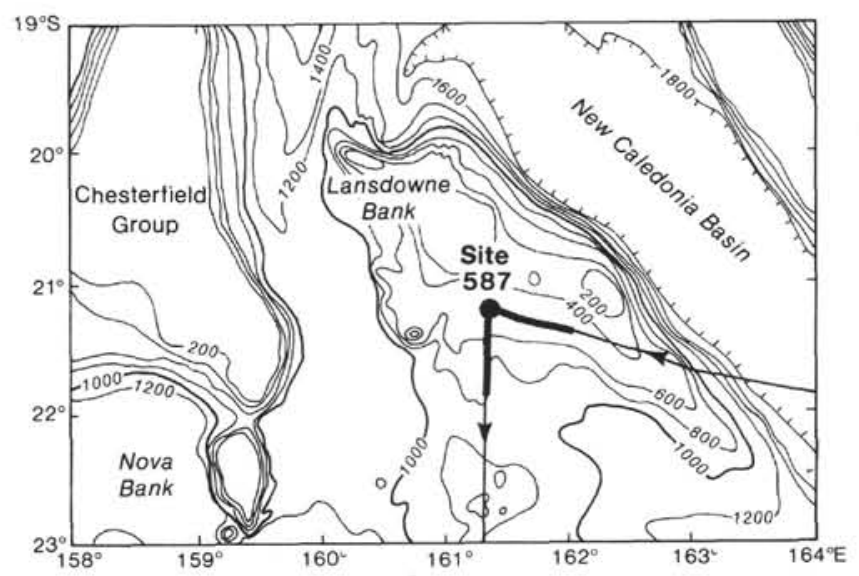

Figure 1. Regional bathymetry (fathoms) around Site 587, after Mammerickx et al. (1974) Glomar Challenger Leg 90 track shown; heavy portion locates water gun seismic profile illustrated in Fig. 2. 


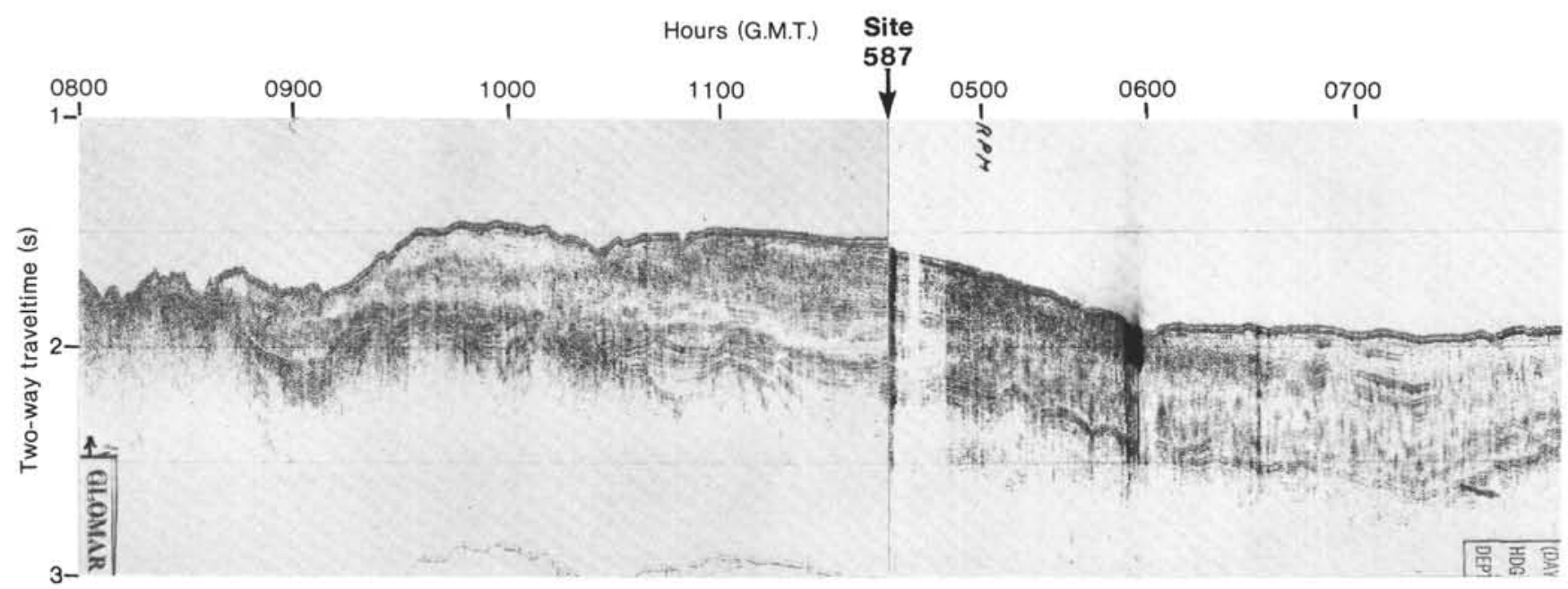

Figure 2. Water gun seismic profile (Glomar Challenger) near Site 587; bandpass filter 40-160 Hz.

be suboptimal, but other areas at these latitudes seemed to be no less complicated.

The specific objectives at Site 587 were to obtain a continuous section through calcareous oozes of late Oligocene and Neogene age near the edge of the tropics. A stratigraphic linkage section was required between two previously drilled sites of high biostratigraphic quality, Site 289 (and 586) on the equator and Site 208 (and 588) at $26^{\circ} \mathrm{S}$ in warm subtropics. There was particular interest in establishing a biostratigraphic sequence at about $20^{\circ} \mathrm{S}$ to assist with stratigraphic correlations between the equator and the warm subtropics and to monitor paleoceanographic oscillations of the tropical and warm subtropical surface water masses over the region. Approaches to be employed included stable isotope analysis $\left(\delta^{18} \mathrm{O}\right.$ and $\delta^{13} \mathrm{C}$ ), qualitative and quantitative biostratigraphy, sedimentology, and magnetostratigraphy.

To meet these objectives the plan was to recover two hydraulic piston core (HPC) sections and a rotary-drilled section below the point at which the HPC became unusable.

\section{OPERATIONS}

\section{Noumea to Site 587}

The last mooring line was cast off from the Passenger Terminal in Noumea, New Caledonia at 1620 hr. on 2 December 1982, and the Glomar Challenger cleared the barrier reef bordering New Caledonia's southwest coast at $2042 \mathrm{hr}$. after having tested thrusters. Aboard were the normal complement of 45 Global Marine, Inc., personnel plus 28 technical staff and scientists.

Routine geophysical data were collected under way to Site 587 (SW-8), using a $12-\mathrm{kHz}$ echo sounder, a $3.5-\mathrm{kHz}$ reflection profiler, a magnetometer, and a water gun seismic profiling system. The water gun system, incorporating a MICA T model water gun of Seismic Systems, Inc. (80 cu. in. air requirement per shot) was a relatively new addition to Glomar Challenger's suite of underway geophysical equipment, and was used in place of the standard 60 and $120 \mathrm{cu}$. in. air guns. Records obtained by the water gun appeared superior to those obtained using the air guns, with excellent penetration (in excess of $1 \mathrm{~s}$ two-way traveltime), a subdued bubble-pulse, and resolution of fine sub-bottom reflectors.

The few seismic profiles which were available for site selection at Site 587 indicated simple Neogene stratigraphy and sub-bottom structure over a relatively broad area around the proposed location. Because of this, and because the major objective of drilling this site was to core the Neogene section, a presite survey was considered unnecessary. Consequently, the Elf-Aquitaine multichannel seismic Line WNC 109 (used for initial site selection) was intersected by the track of Glomar Challenger some $14 \mathrm{n}$. mi. southeast of the proposed drill site. Seismic Line WNC 109 then was followed to the site.

The ship averaged 10.6 knots for the $170.2 \mathrm{mi}$. transit, aided by favorable weather and currents.

The first of two positioning beacons was launched on the first pass at $2243 \mathrm{hr}$., 3 December 1982. A second beacon was required when the first proved to be too erratic for automatic positioning.

\section{Site 587 (SW-8); South of Lansdowne Bank, Northern Lord Howe Rise}

A special bottom-hole assembly (BHA) was assembled and checked for spacing to accommodate the latest version of the extended core barrel (XCB), a throughthe-bit rotary coring tool, which was being deployed for the first time since Leg 84. The BHA was also configured to accommodate the conventional variable length HPC (VLHPC). By this means, piston coring to refusal could be followed immediately by rotary (XCB) coring to the objective without a pipe round trip to change bits.

Hole 587 was spudded at $1355 \mathrm{hr}$., 4 December 1982 with a mud line VLHPC core containing $3.1 \mathrm{~m}$ of calcareous ooze (Table 1). Drill pipe measured (DPM) depth of $1115 \mathrm{~m}$ from the rig floor reference elevation proved to be $4 \mathrm{~m}$ greater than the depth measured by the precision depth recorder (PDR).

All appeared well until Core 2 came up empty, apparently because the core catcher failed. Because the BHA was so near the mud line, a second shot was taken at Core 2, but very little core was recovered because of a mechanical failure in the VLHPC. This was quickly rec- 
Table 1. Coring Summary, Site 587.

\begin{tabular}{|c|c|c|c|c|c|c|c|}
\hline Core & $\begin{array}{l}\text { Date } \\
\text { (Dec. }\end{array}$ & & $\begin{array}{l}\text { Depth from } \\
\text { drill floor } \\
\text { (m) }\end{array}$ & $\begin{array}{l}\text { Depth below } \\
\text { seafloor } \\
\text { (m) }\end{array}$ & $\begin{array}{l}\text { Length } \\
\text { cored }\end{array}$ & $\begin{array}{l}\text { Length } \\
\text { recovered }\end{array}$ & Percentage \\
\hline no. & & Time & Top Bottom & Top Bottom & & & recovered \\
\hline 1 & 4 & 1445 & $1115.1-1118.2$ & $0.0-3.1$ & 3.1 & 3.08 & 100 \\
\hline 2 & 4 & 1800 & $1118.2-1127.8$ & $3.1-12.7$ & 9.6 & 9.51 & 99 \\
\hline 3 & 4 & 1850 & $1127.8-1137.4$ & $12.7-22.3$ & 9.6 & 8.86 & 92 \\
\hline 4 & 4 & 1940 & $1137.4-1147.0$ & $22.3-31.9$ & 9.6 & 9.71 & 100 \\
\hline 5 & 4 & 2030 & $1147.0-1156.6$ & $31.9-41.5$ & 9.6 & 9.53 & 99 \\
\hline 6 & 4 & 2120 & $1156.6-1166.2$ & $41.5-51.1$ & 9.6 & 9.58 & 100 \\
\hline 7 & 4 & 2225 & $1166.2-1175.8$ & $51.1-60.7$ & 9.6 & 8.86 & 92 \\
\hline 8 & 4 & 2305 & $1175.8-1185.4$ & $60.7-70.3$ & 9.6 & 9.82 & 100 \\
\hline 9 & 4 & 0005 & $1185.4-1195.0$ & $70.3-79.9$ & 9.6 & 2.46 & 26 \\
\hline 10 & 4 & 0045 & $1195.0-1204.6$ & $79.9-89.5$ & 9.6 & 9.54 & 96 \\
\hline 11 & 4 & 0145 & $1204.6-1214.2$ & $89.5-99.1$ & 9.6 & 7.86 & 83 \\
\hline 12 & 4 & 0400 & $1214.2-1218.7$ & $99.1-103.6$ & 4.5 & tr & 0 \\
\hline 13 & 4 & 0630 & $1218.7-1223.7$ & $103.6-108.6$ & 5.0 & $\mathrm{CC}$ & 0 \\
\hline 14 & 4 & 0800 & $1223.7-1233.3$ & $108.6-118.2$ & 9.6 & 0 & 0 \\
\hline 15 & 4 & 0915 & $1233.3-1242.9$ & $118.2-127.8$ & 9.6 & 0 & 0 \\
\hline 16 & 4 & 1015 & $1242.9-1252.5$ & $127.8-137.4$ & 9.6 & tr & 0 \\
\hline \multirow[t]{2}{*}{17} & 4 & 1110 & $1252.5-1262.1$ & $137.4-147.0$ & 9.6 & 0 & 0 \\
\hline & & & & & 147.00 & 88.81 & $60.4 \%$ \\
\hline
\end{tabular}

tified, the tool was realigned for orientation, and coring continued with a third and successful attempt to obtain Core 587-2.

VLHPC coring in $9.5 \mathrm{~m}$ increments continued with good results until Core 587-12 (Table 1). At this point ( $99.1 \mathrm{~m}$ below the seafloor) a sudden change in lithology occurred as the sediment became brittle, coarse, and loosely cemented, compared to the fine, consolidated ooze encountered up to that point. Penetration of the corer fell off markedly and recovery dropped to mere traces. Virtually no usable core was recovered on VLHPC Cores 587-12 and 587-13.

The XCB was deployed for Cores 587-14 through 587-17. Despite all indications that the tool functioned properly, only traces of sediments could be found in the core barrel. Various penetration, flow rate, and corecatcher configurations were attempted but the coarsegrained carbonate sediments proved completely elusive. It could not be conclusively determined whether the core never entered the core liner or did enter but worked its way out during the retrieval.

Three Von Herzen heat-flow runs were made with essentially perfect results, including a good run on Core $587-12$, despite the fact that no core was recovered when the tool was retrieved.

Kuster single-shot orientation shots were taken on each VLHPC core after Core 587-2. A high proportion of the photos were of a quality sufficient to derive useful magnetic orientation data.

The hole was terminated when it became apparent that only minimal scientific data were likely to be acquired and that we had reached a point of diminishing returns, especially in view of higher priorities at future sites. The pipe was tripped and the vessel got under way for Site 588 at $1505 \mathrm{hr}$., 6 December 1982.

\section{LITHOSTRATIGRAPHY}

Site 587 consists of one hole continuously cored with the hydraulic piston corer to a total sub-bottom depth of $147.0 \mathrm{~m}$. Recovery was not complete and much of the sequence experienced severe coring disturbance. The re- covered sequence is from one lithostratigraphic unit (Unit 1) of Quaternary to late Miocene age, but is composed of two lithofacies, $a$ and $b$, that are interbedded throughout the length of the section.

The major lithofacies, a, is a foraminifer-bearing to foraminifer-nannofossil ooze. The percentages of foraminifers (Fig. 3) generally vary between about 5 and $50 \%$. Calcareous nannofossils are abundant to dominant and nearly always make up greater than $50 \%$ of the sample. Detrital minerals are almost completely lacking with only a few small fragments of quartz, feldspar, and volcanic glass in some smear slides. Lithofacies a varies in color from white or very light gray to light bluish gray; there is no trend with depth. Throughout this lithofacies, there occasionally occur laminae, streaks, mottles, and small $(1 \mathrm{~mm})$ pockets of medium gray to very light gray disseminated inclusions of fine-grained authigenic iron sulfide (pyrite?) and chemical diffusion bands of medium and light medium gray. Burrows appear to be infrequent, but this may be due, in part, to the lack of good cores. The ooze is soft at the top of the sequence, becomes stiff by about $50 \mathrm{~m}$ sub-bottom, and by $90 \mathrm{~m}$ sub-bottom clasts of chalk occur.

The major lithofacies a is interbedded with a coarsegrained lithofacies b which consists of skeletal silty sands to skeletal sandy gravels. These interbeds are yellow gray and, less commonly, pinkish gray. The yellow gray color is distinctive and is principally derived from coaser silt, sand, and gravel-sized skeletal tests and fragments of planktonic and benthic foraminifers, calcareous red and green algae (including Halimeda), corals, bryozoa, and echinoid spines, as well as abundant, fine, indeterminate biogenic detritus and common skeletal carbonate lithoclasts (Fig. 4). The interbeds are massive or normally graded, subtly in the finer-grained deposits, and are typically less than 1 to $2 \mathrm{~m}$ thick. Clasts and irregular or disrupted layers of the foraminifer-bearing nannofossil ooze (or chalk) occur sporadically throughout the interbeds.

The occurrence of normal grading and shallow-marine biogenic detritus in the interbeds indicates that they are redeposited beds. However, interpretation is complicated by the fact that most of the skeletal debris occurs at or near the tops of cores, which may mean that some of these interbeds represent contamination from wash and cave-in during coring. Presumably, this material could be from the topmost $6 \mathrm{~m}$ of seabed, because Cores 587-1 and 587-2 are dominated by a disturbed sequence of coarse skeletal hashes of Pleistocene age (nannofossil Zone NN21).

Late Miocene chalk clasts and layers in Core 587-11 ( 89.5 to $99.1 \mathrm{~m}$ sub-bottom) appear to be stratigraphically in situ and represent episodes of sediment redeposition. The clasts are nannofossil-bearing chalks and include longer-ranging Neogene nannofossils and poorly preserved Cretaceous and Paleogene specimens (Table 2). The paleontologic evidence suggests reworking of the preNeogene nannofossils into an earlier Miocene ooze that subsequently became partially lithified, eroded, and redeposited into the late Miocene sequence. The chalk clast 

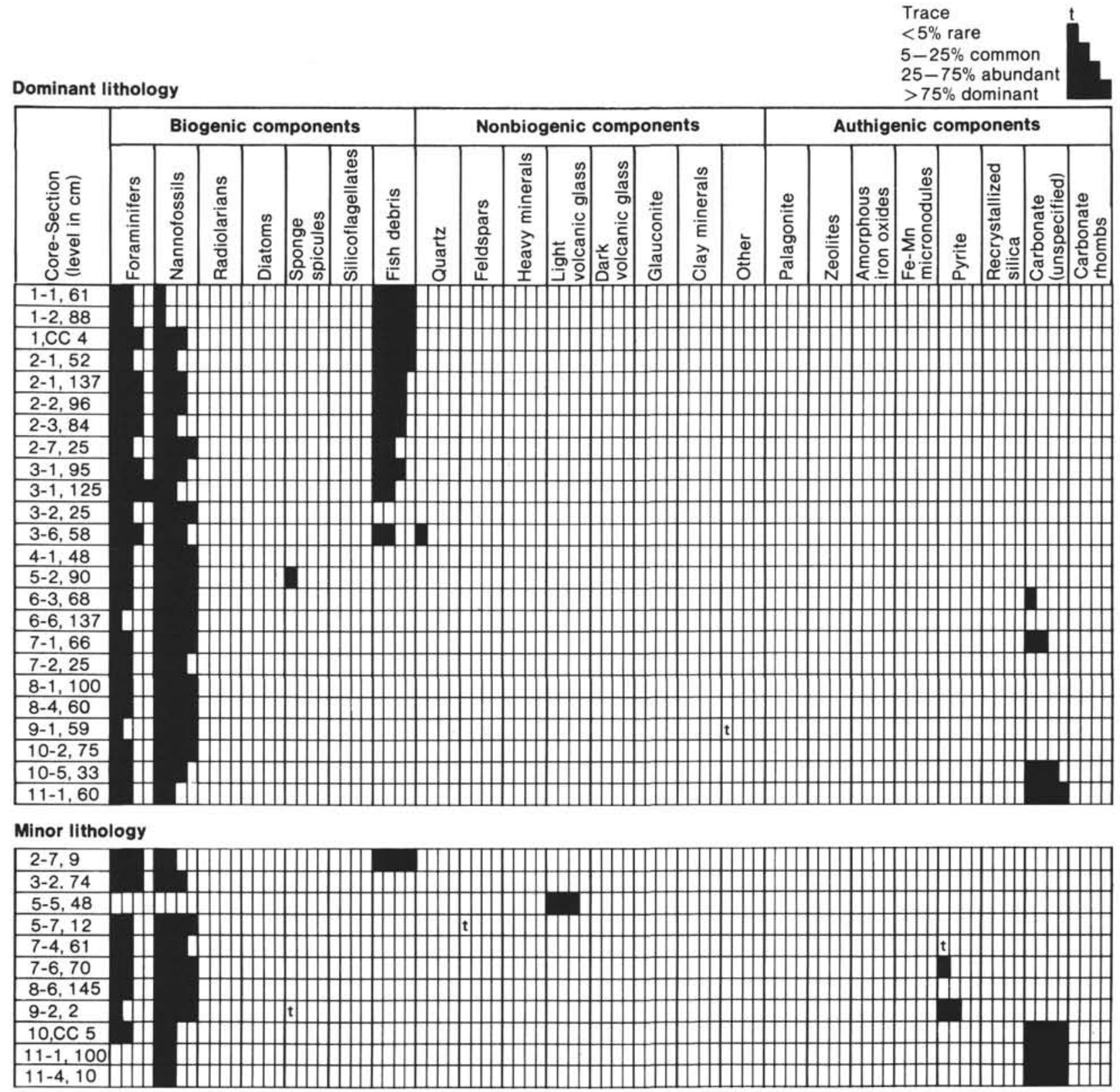

Figure 3. Summary of smear slide observations from dominant and minor lithologies.

layers may, in fact, be the coarse basal portion of proximal turbidites in which the finer portions are the skeletal, muddy, fine sands.

\section{PHYSICAL PROPERTIES}

The physical properties program for Site 587 consisted of employing gravimetric and gamma-ray attenuation techniques (Boyce, 1976) to determine wet-bulk density, porosity, and grain density throughout the sediment column. Carbonate content and thermal conductivity were also measured as functions of depth (see Explanatory Notes for details of methods). Plans to measure sonic velocity and to obtain specimens for shore-based permeability tests from a second hole were abandoned since coring of the adjacent hole was cancelled.

The GRAPE provides measurements of wet-bulk density versus depth. The distinct values (points) are aver- aged across each meter and plotted as a solid line (Fig. $5 \mathrm{~A}$ ). A grain density estimate of $2.691 \mathrm{~g} / \mathrm{cm}^{3}$ is used to convert sediment wet-bulk density to porosity. Since the carbonate content at this site is very high, never dropping below $90 \%$ (Fig. 5B), this conversion factor provides a reasonable estimation of porosity profile (Fig. 5C). A gradual decrease in porosity with depth and corresponding lithostatic load is evident. A transition from ooze to chalk was not reached, however, over the $89 \mathrm{~m}$ of core recovered. The physical properties for Site 587 are reported in detail by Morin (this volume).

\section{SEISMIC STRATIGRAPHY}

Figure 6 illustrates a portion of the shipboard water gun seismic profile collected during the approach to Site 587. Three acoustic units have been identified (A, B, 

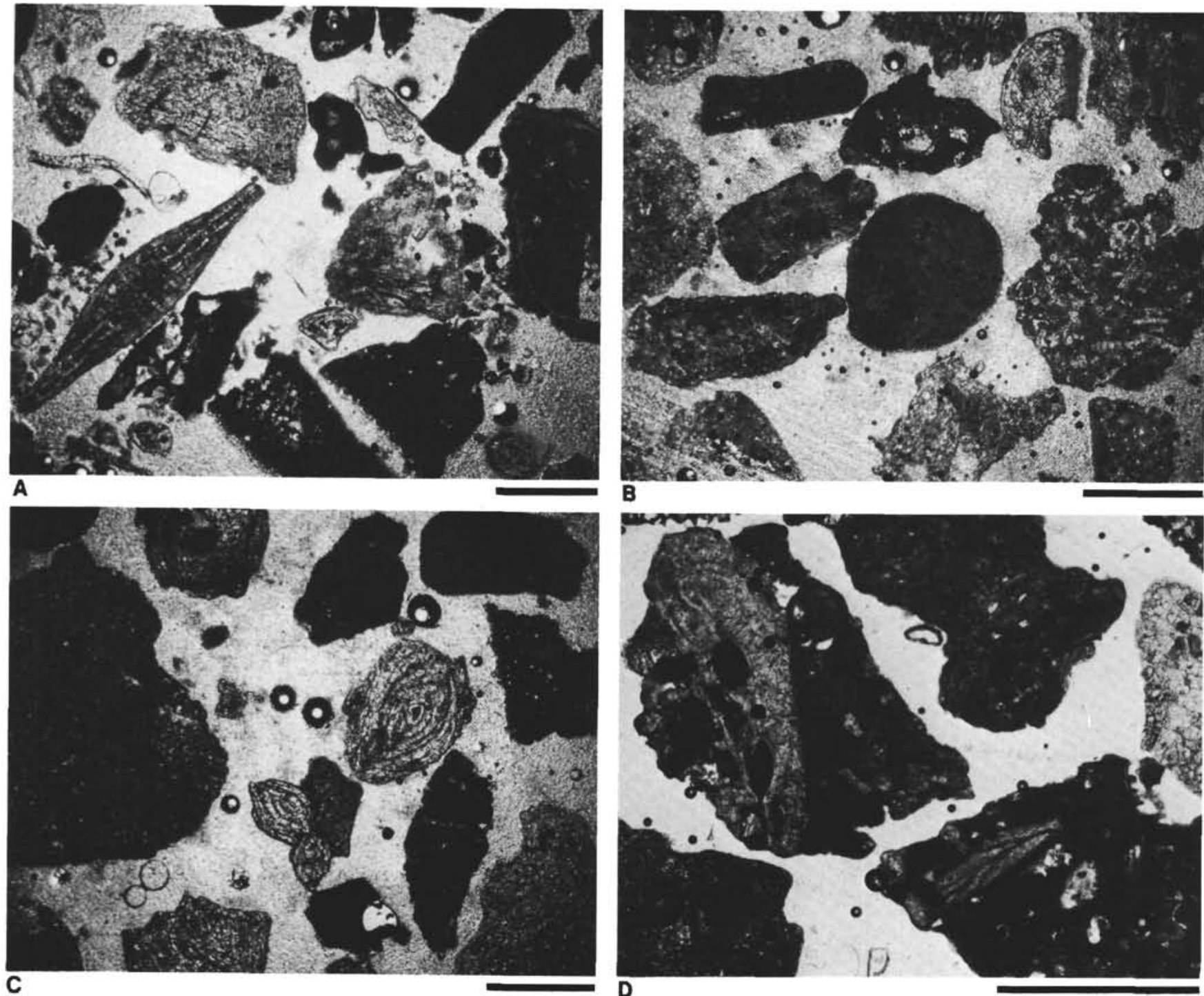

Figure 4. Photomicrographs of typical shallow-marine carbonate components in the redeposited coarse-grained sediment facies at Site 587. Plane polarized light, bar scale $1 \mathrm{~mm}$. A. Dark Halimeda grains, lighter coral fragments, and large benthic foraminifers in Sample 587-1-2, 65-67 cm. B. Abraded grains of calcareous red and green algae, and bryozoan, coral, benthic foraminiferal, and irregular carbonate lithoclast material in $587-13$, CC. C. Large bryozoan and dark Halimeda, coral, and benthic foraminiferal material in 587-13,CC. D. Irregular carbonate lithoclasts of skeletal packstone and wackestone in 587-13,CC.

and C). These are compared in part with the lithology of the site (Lithostratigraphic Unit I).

Acoustic Unit A is acoustically well stratified, characterized by relatively high amplitude and locally relatively coherent reflectors. The uppermost zone, in the region below the reflected wave-form down to $0.1 \mathrm{~s} \mathrm{~s}{ }^{3}$ is slightly more transparent than the underlying portion of Unit A. This upper zone also exhibits a possible buried channel adjacent to the drill site, and the sediment surface is dissected by an unfilled channel several miles to the east (Fig. 6). A diffuse zone of greater transparency is evident between 0.2 and $0.26 \mathrm{~s}$ sub-bottom. The lower boundary of Unit A grades down into Unit B.

Acoustic Unit B is more transparent than Unit A. The upper zone $(0.325-0.45 \mathrm{~s})$ is characterized by diffuse,

\footnotetext{
${ }^{3}$ Depths quoted in text as seconds below seafloor have been measured below Site 587.
}

Table 2. Some nannofossil species associated with chalk chunks from Section 587-11-1.

\begin{tabular}{llll}
\hline \multicolumn{1}{c}{ Species } & Abundance & Preservation & Age \\
\hline Coccolith sp. (small) & Common & Fair & \\
Coccolithus pelagicus & Few & Fair-poor & Cenozoic \\
Reticulofenestra pseudoumbilica & Rare & Fair & Neogene \\
Pontosphaera sp. & Rare & Poor & Cenozeic \\
Discoaster brouweri & Rare & Fair & Neogene \\
Helicosphaera carteri & Rare & Poor & Neogene \\
Sphenolithus abies & Rare & Fair & Neogene \\
Dictyococcites sp. cf. D. scrippsae & Few & Fair-poor & Paleogene \\
Scyphosphaera intermedia & Rare & Very poor & Cenozoic \\
Eiffellithus turriseiffeli & Rare & Very poor & Cretaceous \\
Watznaueria barnesae & Rare & Very poor & Cretaceous \\
Arkhangelskiella cymbiformis & Rare & Very poor & Cretaceous \\
\hline
\end{tabular}

noncoherent reflectors. Between 0.45 and $0.55 \mathrm{~s}$ sub-bottom, a well-defined transparent zone is evident.

Acoustic Unit C is separated from B by the uppermost of a series of strong, coherent reflectors which con- 

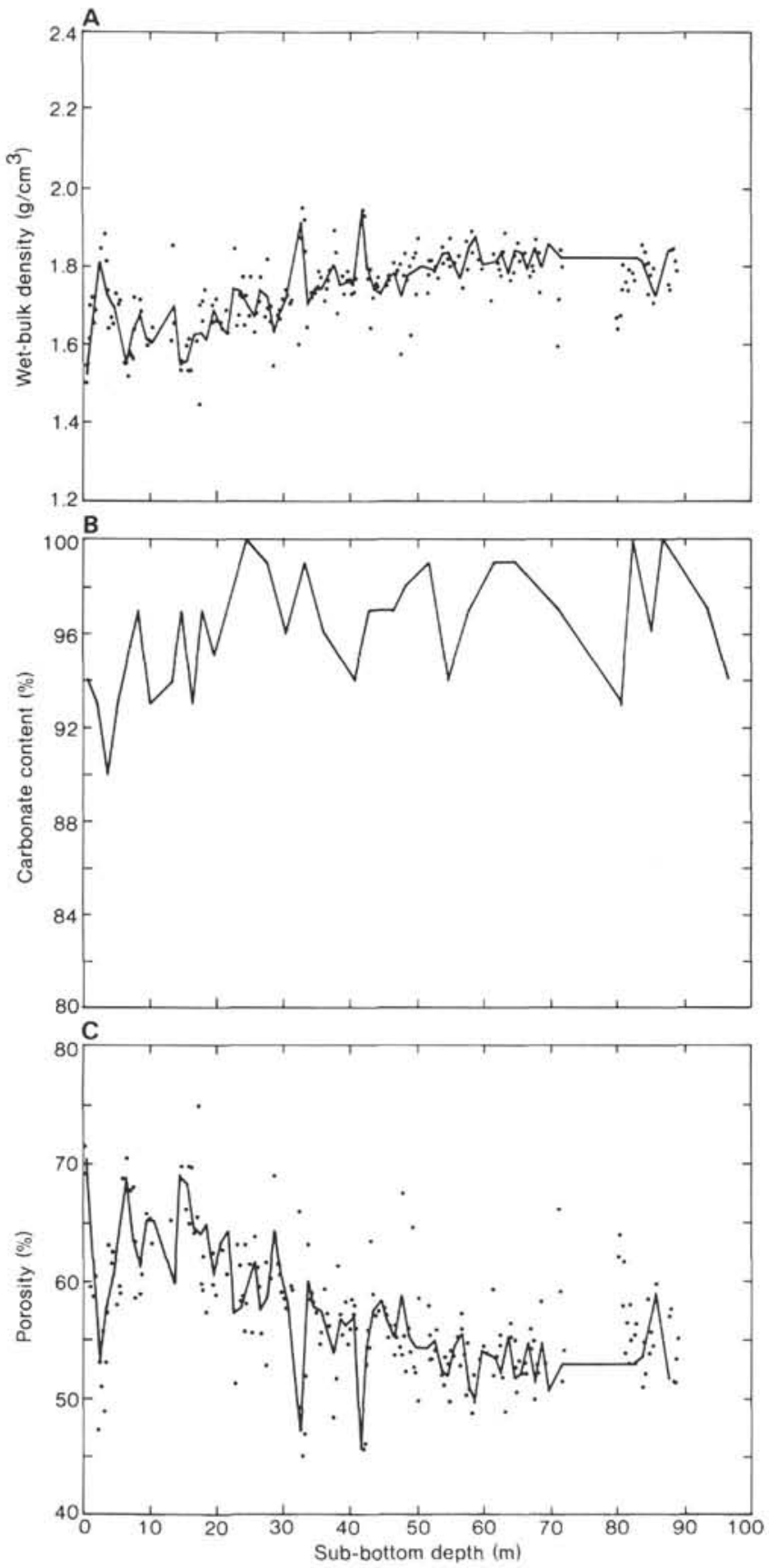

Figure 5. Physical properties versus sub-bottom depth for Site 587. A. GRAPE wet-bulk density. B. Carbonate content. C. GRAPE porosity.

stitute Unit C. Unit C at Site 587 continues below the limit of the figure.

Site 587 was drilled to a total depth of $147 \mathrm{~m}$, within the uppermost portion of seismic Unit A. It comprises a single lithological unit (Unit I) of late Miocene to recent age, characterized by interbedded foraminifer-bearing to foraminifer-nannofossil ooze and skeletal sands to skeletal sandy gravels. The skeletal sands and gravels are reworked, perhaps as debris flows or turbidites from neighboring shallow banks. This coarse-grained facies appears to dominate the section in Cores 587-1 and 587-2 (Pleis- tocene) and from the lower portion of Core 587-10 at least through Core 587-11 (NN11, late Miocene). Below Core 587-12 to the bottom of the hole at Core 587-17 recovery was essentially zero, suggesting the presence of additional sand- and gravel-rich sections.

Correlation of the seismic and lithologic data suggests that the upper bioclastic sections (Cores 587-1 and 587-2) are genetically associated with the surficial and buried channels shown on Figure 6. These channels are probably Pleistocene features caused by episodes of redeposition during periods of low sea level. The zone of almost $100 \%$ core recovery in the calcareous-ooze-rich sequence (Cores 587-3 through 587-10, with the exception of 587-9) may correlate with the relatively transparent upper zone of seismic Unit A. The lower portion of the sequence (lowermost Core 587-10, possibly through 587-17) may correlate with the uppermost acoustically stratified portion of seismic Unit A, approximately $0.1 \mathrm{~s}$ sub-bottom.

\section{BIOSTRATIGRAPHY}

The preservation of planktonic foraminifers is reasonably good in the Pliocene-Pleistocene but deteriorates rapidly in the late Miocene; the faunal yield is disappointing, especially in the Pliocene and late Miocene, where zonal indicators are either absent or present only in low numbers. Benthic foraminiferal faunas are found to be mixtures of allochthonous and autochthonous species.

The sedimentation rate of sediments in the Pliocene and late Miocene was $24.5 \mathrm{~m} / \mathrm{m}$.y., decreasing upsection to $16.6 \mathrm{~m} / \mathrm{m} . \mathrm{y}$. in the Quaternary.

The calcareous nannoplankton are abundant and moderately well preserved in the Quaternary through to the upper part of the late Miocene, but preservation and numbers deteriorate throughout the remainder of the late Miocene. No radiolarians, diatoms, or silicoflagellates were found in the smear slides.

Fish otoliths were recovered in Cores 1 to 3 . Microfossil preservation was very poor in Core 3 .

Calcareous nannoplankton zones and planktonic foraminiferal zones are correlated in Figure 7.

\section{Foraminifers}

\section{Planktonic Foraminifers}

The planktonic foraminifers from the 13 sediment cores containing material at this site represent a section from Pleistocene to upper Miocene. Only the fossils in the Pleistocene and Pliocene sediments are well preserved. Numbers and preservation of the planktonic foraminifers both deteriorate downward in the upper Miocene. The Neogene sequence at this site contains a mixture of tropical and temperate planktonic foraminiferal elements, providing a link between those of the tropical Site 586 (289) and the cooler water faunas of the sites drilled further south (Site 588, 590, 591, 592, 593, and 594).

A detailed analysis of the faunas reveals that Blow's (1969) zonal scheme cannot be used for the site because of the scarcity of index planktonic foraminifers in the 


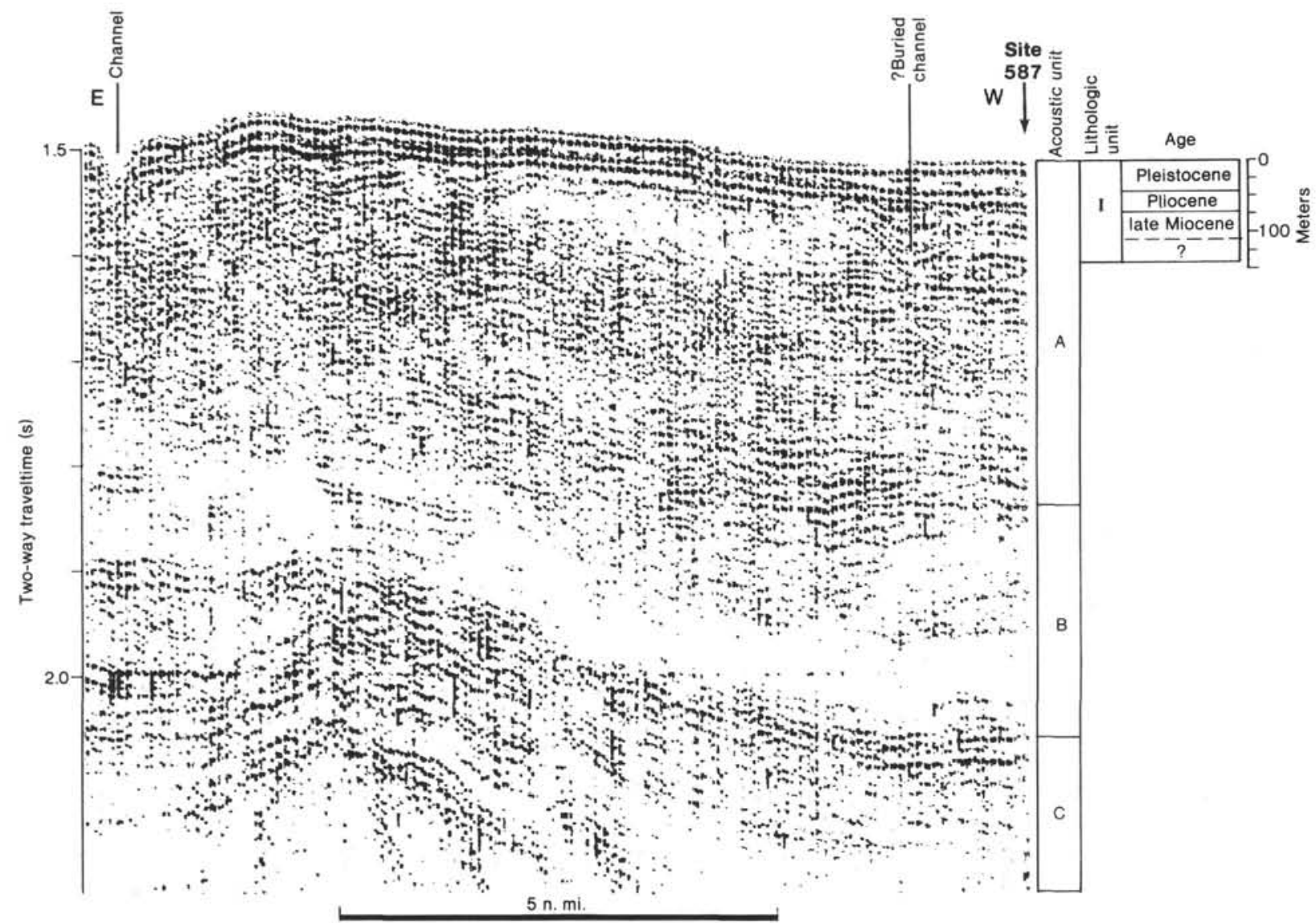

Figure 6. Comparison of acoustic Units A-C with Lithostratigraphic Unit I cored at Site 587; shipboard water gun seismic profile, collected during site approach; depths in meters estimated by assuming a sediment sound velocity of $2000 \mathrm{~m} / \mathrm{s}$.

Pleistocene and Pliocene sequence. Tropical elements dominate in the late Miocene, whereas temperate elements dominate in the Pliocene-Pleistocene sequence, although many tropical elements persist. Thus, biostratigraphic subdivision of the late Miocene requires use of the tropical zones (Srinivasan and Kennett, 1981a), whereas the Pliocene-Pleistocene sequence requires the use of the temperate zones of Kennett (1973). The zonal scheme employed at the site is shown in Figure 7. The Globorotalia truncatulinoides Zone in Sample 587-1-1, 5-6 cm through 587-3-2, 19-20 cm yielded a well-preserved, highly diverse fauna which includes the zone fossil, $G$. truncatulinoides, Pulleniatina obliquiloculata, G. tumida, and $G$. inflata. Reworked Pliocene foraminifers are detectable in 587-1,CC and in other samples.

Samples 587-3-3, 19-20 cm through 587-4,CC yielded faunas of Globorotalia truncatulinoides-G. tosaensis overlap Zone, which yielded the zone fossils, G. truncatulinoides, G. tosaensis, G. menardii, and Sphaeroidinella dehiscens. In the lower part of the zone Globigerinoides fistulosus, a late Pliocene index form, occurs in association with Globorotalia truncatulinoides.

The G. tosaensis Zone in Sample 587-5-1, 114-115 cm through 587-5-4, 90-91 cm yielded the zone fossil in a highly diverse fauna, which also includes $P$. obliquiloculata, G. menardii, G. inflata, G. puncticulata, G. crassaformis, and rare Globigerinoides fistulosus.
Planktonic foraminiferal determinations place the Pleistocene/Pliocene boundary between Samples 587-4,CC and $587-5-1,114-115 \mathrm{~cm}$. The boundary is drawn at the first evolutionary appearance of Globorotalia truncatulinoides.

The $G$. inflata Zone, from Sample $587-5-5,80-81 \mathrm{~cm}$ through $587-5, \mathrm{CC}$, yielded a nicely preserved, well-diversified fauna, which includes the zone fossil, $G$. menardii, G. multicamerata, G. crassaformis, G. tumida, and P. obliquiloculata.

The G. crassaformis Zone, which was identified in Sample 587-6-1, 85-86 cm through 587-6-3, 89-90 cm, yielded a rich fauna. Globigerina nepenthes and Globorotalia $\mathrm{cf}$. miotumida make their last appearance in the lower part, and $G$. margaritae is present in the upper part of the zone. The first appearance of $S$. dehiscens is in the upper part of the zone, and is much later than at the tropical Site 289 (Kennett, 1973; Srinivasan and Kennett, 1981a,b).

Samples 587-6-4, 85-86 cm through 587-6-5, 85-86 cm yielded faunas of the Globorotalia puncticulata Zone, which include the zone fossil, $P$. primalis, $G$. cf. miotumida, G. tumida tumida, G. menardii, and G. multicamerata. The base of the zone is marked by the first appearance of $G$. puncticulata. As was true for the warm subtropical sites, the evolutionary bioseries is not represented. 


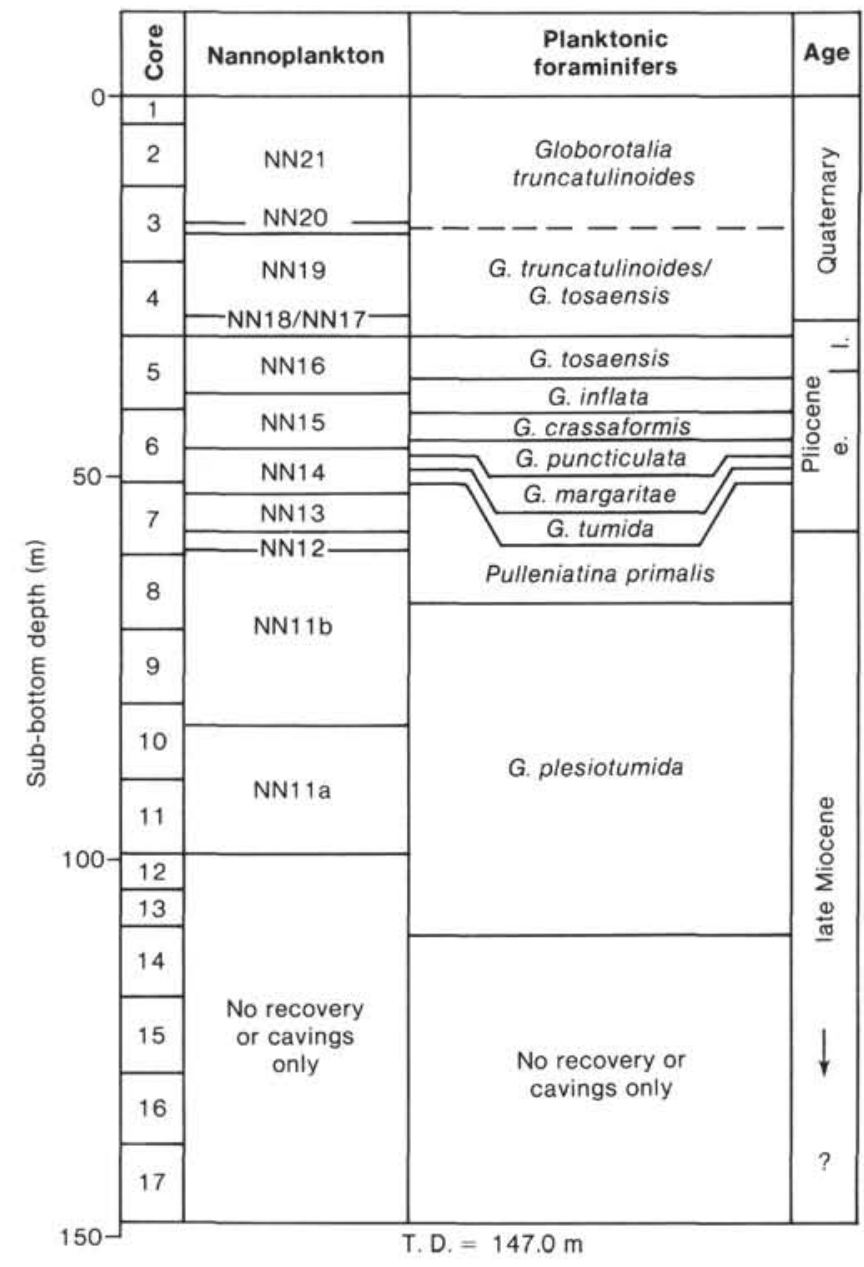

Figure 7. Biostratigraphy of Hole 587.

The Globorotalia margaritae Zone was identified in Sample 587-6-6, 53-56 cm and 587-6-6, 124-125 cm; it yields the zone fossil in association with $G$. cf. miotumi$d a$, G. tumida tumida, and P. primalis.

The Globorotalia tumida Zone ( $=\mathrm{N} 18)$ is represented in Samples 587-6-7, 11-12 cm through 587-6,CC, which yielded an excellent fauna including the zone fossil, Globigerina nepenthes, Globorotalia menardii, Dentoglobigerina altispira, and $P$. primalis.

The Miocene/Pliocene boundary is placed between Samples 587-6,CC and 587-7-1, 59-60 cm; the boundary is drawn at the first evolutionary appearance of Globorotalia tumida tumida.

The Pulleniatina primalis Zone $(=\mathrm{N} 17 \mathrm{~B})$ is recorded from Sample 587-7-1, 59-60 cm through 587-8-4, 70-71 $\mathrm{cm}$ which again yielded reasonable faunas, including the zone fossil, G. miotumida, Orbulina bilobata, G. plesiotumida, Neogloboquadrina acostaensis, and G. cibaoensis.

The $G$. plesiotumida Zone ( $=\mathrm{N} 17 \mathrm{a})$ is represented in the interval from Samples 587-8-5, 70-71 cm through $587-13, \mathrm{CC}$. The faunas in these samples besides the zone fossil, include G. miotumida, G. multicamerata, Globigerina nepenthes, and $N$. acostaensis. Candeina nitida makes its first appearance in Sample 587-10-6, 17-18 cm, and Globoquadrina dehiscens makes its last appearance within the zone (Sample 587-10-5, 17-18 cm).

\section{Benthic Foraminifers}

Benthic foraminifers were examined in core-catcher Samples 587-1-9,CC and 587-10-13,CC from the fraction of the sediment greater than $63 \mu \mathrm{m}$. Each fauna contains an allochthonous and an autochthonous element; the allochthonous benthics are considered to be derived from a carbonate platform back-reef to beach environment.

Allochthonous benthic foraminifers and some other invertebrates are most common in Cores 587-1 through 587-3 and 587-10 through 587-13, in which few if any bathyal species are present. Typical constituents of this element are bryozoa, heavily spinose ostracodes, numerous miliolids including ornamented quinqueloculinids, and Articulina scrobiculata, Tretomphalus pacificus, Uvigerina porrecta, Elphidium macellum, E. crispum, and E. cf. advenum, Amphistegina sp., Cymbaloporella sp., and several larger benthic genera. Considering the amount of carbonate debris in each core-catcher sample, it appears that the depositional mode changed from the Miocene (Cores 587-10 through 587-13), characterized by large, pure shallow-water deposits, to the upper PliocenePleistocene (Cores 587-5 through 587-1), which is characterized by redeposited shallow-water elements within marl deposit.

Miocene faunas (Cores 587-7 through 587-9) include Laticarinina bullbrooki, Uvigerina auberiana, Cibicidoides bradyi, Osangularia culter, Gyroidinoides nitidula, Bulimina alazanensis, and Robulus nicobarensis, as well as many long-ranging species listed below in the discussion about the Quaternary.

Within the Pliocene (Cores 587-5 and 587-6), faunas can be differentiated into glacial (Core 587-5) and preglacial (Core 587-6). Faunas of Core 587-5 resemble those of the Pleistocene, except that they are rarer and more difficult to separate from the chalky matrix. The preglacial faunas of Core 587-6 contain taxa typical of the Miocene at this site; several of them, such as Rectuvigerina multistriata, Bolivina subaenariensis, $C$. cicatricosus, and Heterolepa kullenbergi, do not range above Core 587-6.

Quaternary autochthonous faunas (Core 587-1 through Sample 587-4,CC) contain many long-ranging, cosmopolitan species such as Karreriella bradyi, Globocassidulina subglobosa, Cibicides wuellerstorfi, Cassidulina crassa, Sigmoilopsis schlumbergeri, Stilostomella lepidula, U. hispida, Bulimina striata, and Ehrenbergina pacifica. Species are considered to be autochthonous if they are common in Cores 587-7 through 587-9, which contain much less evidence of redeposited carbonates, if they appear consistently in sediments from the deeper Site 586 , and if they are known from the bathyal zone in others areas.

Comparison of the faunas at Site 586 (closer to $2200 \mathrm{~m}$ ) and Site $587(1101 \mathrm{~m})$ indicate that the following species are restricted to the shallower site: $R$. multistriata, Robulus nicobarensis, E. pacifica, S. raphanus, U. nitidu- 
la, and $O$. culter. Osangularia bengalensis, B. pusilla, Sphaeroidina bulloides, Pullenia quinqueloba, among others, were found at the deeper Site 586, but not at Site 587.

\section{Calcareous Nannoplankton}

Samples from Cores 1 through 9 contain abundant moderately to well-preserved nannoplankton. Samples below $587-10, C C$ contain rare to few poorly preserved nannoplankton. The boundary between NN21 and NN20 was not observed, but all other zones down to NN11a are present.

\section{Pleistocene}

The presence of Emiliania huxleyi in Samples 587-1-1, 4-5 cm to $587-3-3,20-21 \mathrm{~cm}$ places these samples in the late Pleistocene Emiliania huxleyi Zone (NN21). The rare occurrence of Discoaster brouweri, D. pentaradiatus, and Ceratolithus rugosus in Sample 587-1,CC is interpreted as reworked late Pliocene. The presence of E. ovata and the absence of Calcidiscus macintyrei in Samples 587-3-4, $20-21 \mathrm{~cm}$ to $587-4-4,4-5 \mathrm{~cm}$ place these samples in the upper subzone of the early Pleistocene Emiliania ovata Zone (NN19b). The missing Gephyrocapsa oceanica Zone (NN20) may be present between Samples 587-3-3, 20-21 $\mathrm{cm}$ and $587-3-4,20-21 \mathrm{~cm}$. The presence of $E$. ovata and C. macintyrei in Sample 587-4-5, 4-5 cm places this sample in the lower subzone in the $E$. ovata Zone (NN19a).

\section{Pliocene}

The presence of Discoaster brouweri and absence of D. pentaradiatus in Sample 587-4-6, 4-5 cm place this sample in the late Pliocene Discoaster brouweri Zone (NN18). Sample 587-4,CC contains D. pentaradiatus with $D$. brouweri, placing it in the late Pliocene $D$. pentaradiatus Zone (NN17). The last occurrence of $D$. surculus in Sample 587-5-1, 106-107 cm places Samples 587-5-1, $106-107 \mathrm{~cm}$ to $587-5-5,4-5 \mathrm{~cm}$ in the late Pliocene $D$. surculus Zone (NN16).

The presence of Reticulofenestra pseudoumbilica and the absence of Amaurolithus tricorniculatus in Samples 587-5-6, 4-5 cm to 587-6-4, 4-5 cm place these samples in the early Pliocene Reticulofenestra pseudoumbilica Zone (NN15). Samples 587-6-5, 4-5 cm to 587-7-1, 4-5 cm contain $A$. tricorniculatus together with $D$. asymmetricus, which places these samples in the early Pliocene $D$. asymmetricus Zone (NN14). The presence of Ceratolithus rugosus and the absence of D. asymmetricus in Samples 587-7-2, 4-5 cm and 587-7-3, 4-5 cm place this interval in the early Pliocene Ceratolithus rugosus Zone (NN13). The absence of C. rugosus in Sample 587-7-4, 4-5 cm places this sample in the early Pliocene Amaurolithus tricorniculatus Zone (NN12).

\section{Miocene}

Samples $587-7-5,4-5 \mathrm{~cm}$ to $587-10-1,12-13 \mathrm{~cm}$ contain Discoaster quinqueramus along with $A$. primus, which places the samples in the upper subzone of the late Miocene Discoaster quinqueramus Zone (NN11b).

Samples 587-10,CC and 587-11,CC are recrystallized and cannot be assigned an age. Sample $587-16, C C$ is composed of a yellow and a gray fraction. The gray fraction is interpreted as downhole caving from lower Pleis- tocene (NN19) sediments, the yellow sediments are probably upper Miocene.

\section{Diatoms and Silicoflagellates}

Neither fossil group was encountered during routine shipboard smear slide investigation.

\section{Radiolarians}

Radiolarians were not noted in the upper Neogene and Quaternary sediments of Hole 587.

\section{PALEOMAGNETISM}

Shipboard long-core measurements of the horizontal component of NRM were made on Cores 587-1 through $587-7$ at $10-\mathrm{cm}$ intervals. Subsequent laboratory (cryogenic) measurements were made on two specimens per section for Cores 3 through 10. The uppermost two cores were fluid. Cores 587-3 and 587-4 were partly fluid and moderately deformed during drilling. Shipboard interpretation of the long-core declination data was found to be inconsistent with the laboratory results, presumably because the core liner was contaminated and because of the high scatter in directions of these extremely weakly magnetized sediments:

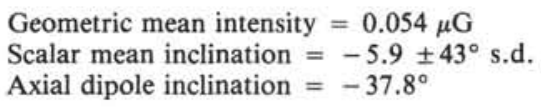

A relatively high intensity zone (typically $0.7 \mu \mathrm{G}$ ) occurred at the top of the sequence above Section 587-5-5, and correlates with the presence of skeletal carbonate. Below Section 587-5-6, intensities dropped to very low values. Prominent intensity spikes occurred at the following depths:

$\begin{array}{ccc}\begin{array}{c}\text { Core-Section } \\ \text { (level in cm) }\end{array} & \begin{array}{c}\text { Depth } \\ (\mathrm{m})\end{array} & \begin{array}{c}\text { Intensity } \\ (\mu \mathrm{G})\end{array} \\ 6-3,25 & 44.75 & 0.131 \\ 8-6,17 & 68.37 & 0.113 \\ 10-2,25 & 81.65 & 0.367 \\ 10-5,100 & 86.90 & 1.109\end{array}$

Within the uppermost high-intensity zone, directions of remanence appear to be serially correlated, but are considered to be unreliable because the sediments were disturbed. In the very weakly magnetized zone below, NRM directions were too scattered to give a reliable magnetic stratigraphy. Measurements were repeatable within a few tens of degrees, so the scatter cannot be attributed to instrumental noise. Viscous overprinting does not appear to be serious because the mean inclination $\left(-5.9^{\circ}\right)$ is close to zero. It seems probable that some of the scatter is due to a secondary chemical remanence associated with the reduction of iron oxides to iron monosulfides (pyrite blebs were common in this sequence).

\section{SEDIMENTATION RATES}

Only the upper part of Site 587 can be used for determining sedimentation rates (Fig. 8), because of zero recovery and caving below Core 587-10.

Quaternary (Cores 587-1 through 587-4) sedimentation rates are $16.6 \mathrm{~m} / \mathrm{m} . \mathrm{y}$. in foraminifer-bearing nannofossil ooze, which is apparently interbedded with ske- 


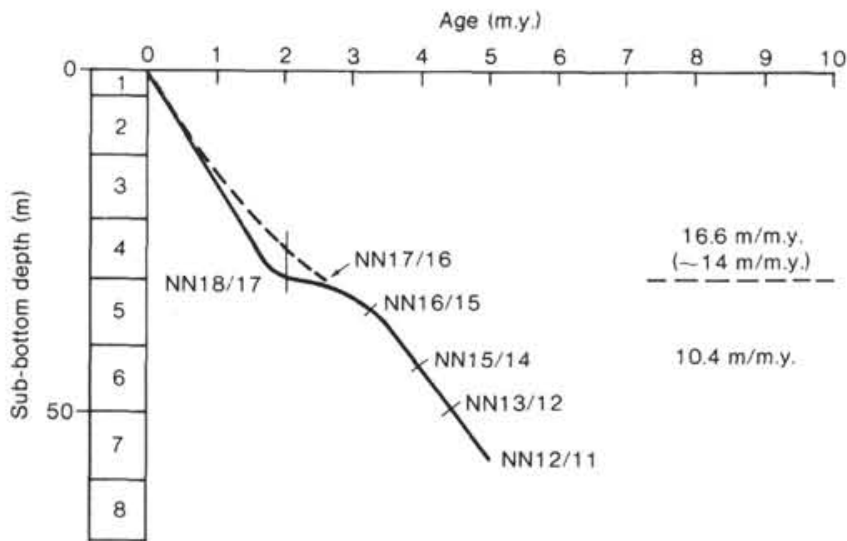

Figure 8. Sedimentation rates at Site 587 based on nannofossil data. Rates not determined below Core 7 .

letal silty sand to skeletal sandy gravel. However, most of the coarser material occurs at the tops of cores, and it may represent material which caved in from the upper Quaternary sediments of Core 587-1. If so, the Quaternary sedimentation rate may not exceed $14.0 \mathrm{~m} / \mathrm{m} . \mathrm{y}$. (dashed line in Fig. 8).

Below Samples $587-4, \mathrm{CC}$ the sedimentation rate is $10.4 \mathrm{~m} / \mathrm{m} . \mathrm{y}$. in foraminifer-bearing nannofossil oozes of Pliocene age.

No datum levels could be distinguished in the upper Miocene skeletal oozes and chalks, and sedimentation rates could not be extrapolated.

\section{SUMMARY AND CONCLUSIONS}

Site 587 is located on the southern slope of Lansdowne Bank in the southwest Pacific at $21^{\circ} \mathrm{S}, 161^{\circ} \mathrm{E}$. The main objective at Site 587 was to obtain a complete Neogene sequence by hydraulically piston coring the upper Neogene sediments to refusal and then rotary coring through the remaining sequence. This site was selected to obtain an uncomplicated, high-resolution record in calcareous sediments of Neogene age between the warm subtropics and the equator. These objectives were largely not met because sandy layers in the upper Miocene sediments prevented core recovery. Nevertheless, a useful latest Miocene through Quaternary record was recovered using the HPC to $99 \mathrm{~m}$. The remaining part of the sequence, to the bottom of the hole at $147 \mathrm{~m}$, recovered only traces of skeletal sandy gravel of probable late Miocene age. All of the Quaternary through late Miocene planktonic foraminiferal and nannoplankton zones are present at Site 587 (Fig. 9).

The recovered sequence is from one lithostratigraphic unit but is composed of two lithofacies (Fig. 9). The major lithofacies is of pelagic origin and is a foraminiferbearing to foraminifer-nannofossil ooze. The minor lithofacies is a coarse-grained sediment consisting of skeletal silty sands to skeletal sandy gravels. This dominates the upper Quaternary and occurs as thinner interbeds in the upper Miocene.
Calcareous nannofossils nearly always make up more than $50 \%$ of the pelagic facies, whereas foraminifers mostly vary between 5 and $50 \%$. Detrital minerals are almost completely lacking. The ooze is soft at the top of the sequence and becomes stiff by about $50 \mathrm{~m}$ sub-bottom; by $90 \mathrm{~m}$ there occur clasts of indurated chalk.

The coarse sediment facies is formed of redeposited sediments of shallow-water origin, especially corals, calcareous algae, bryozoa, and shallow-water foraminifers from the photic zone of nearby banks. A majority of these particles exhibit surface wear, which probably occurred in shallow water and before redeposition. The interbeds are massive or normally graded and are typically less than 1 to $2 \mathrm{~m}$ thick. A few of these layers are found at the tops of cores and thus may represent contamination from wash and caving during coring, presumably from the Quaternary sands. The upper Miocene coarse layers appear to be in place.

Because the coarser redeposited facies occurs in the late Quaternary and probably the late Miocene, which are times of sea level regression, it is suggested that sediment gravity flows or turbidity currents were locally stimulated at times of low sea level stands. The sedimentation rate for the Pliocene was $10.4 \mathrm{~m} / \mathrm{m}$.y., increasing to $16.6 \mathrm{~m} / \mathrm{m}$.y. during the Quaternary. The relatively low rate during the Quaternary is surprising considering the coarser bioclastic sediment facies. One possible explanation for this could be channeling and localized erosion of sediments by turbidity currents, as suggested by nearby channel structures observed on the seismic profile (see Seismic Stratigraphy). The zone of almost $100 \%$ core recovery in the carbonate-ooze-rich sequence is inferred to correlate with an upper, relatively transparent zone of seismic Unit A. The lower sand-rich part of the sequence may correlate with a further acoustically stratified section of Unit A.

Three successful heat flow measurements provide a linear temperature profile of $5.47^{\circ} \mathrm{C} / 100 \mathrm{~m}$.

\section{REFERENCES}

Blow, W. H., 1969. Late middle Eocene to Recent planktonic foraminiferal biostratigraphy. In Brönnimann, P., and Renz, H. H. (Eds.), Proc. 1st Int. Conf. Planktonic Microfossils, Geneva, 1967: Leiden (E. J. Brill), pp. 197-421.

Boyce, R. E., 1976. Definitions and laboratory techniques of compressional sound velocity parameters and wet-water content, wetbulk density, and porosity parameters by gravimetric and gammaray attenuation techniques. In Schlanger, S. O., Jackson, E. D., et al., Init. Repts. DSDP, 33: Washington (U.S. Govt. Printing Office), 931-958.

Kennett, J. P., 1973. Middle and late Cenozoic planktonic foraminiferal biostratigraphy of the southwest Pacific, DSDP Leg 21. In Burns, R. E., Andrews, J. E., et al., Init. Repts. DSDP, 21: Washington (U.S. Govt. Printing Office), 575-639.

Launay, J., Dupont, J., Lapouille, A., Ravenne, C., and de Broin, C. E., 1977. Seismic traverses across the northern Lord Howe Rise and comparison with the southern part (southwest Pacific). Int. Symp. Geodynamics Southwest Pacific, Noumea (New Caledonia): Paris (Editions Technip), pp. 155-164.

Mammerickx, J. L., Chase, T. E., Smith, S. M., and Taylor, I. L. 1974. Bathymetry of the South Pacific (map). Scripps Institution of Oceanography, La Jolla, California, IMR Technical Reports ANB. 
Ravenne, C., de Broin, C. E., Dupont, J., Lapouille, A., and Launay, J., 1977. New Caledonia Basin-Fairway Ridge: structural and sedimentary study. Int. Symp. Geodynamics Southwest Pacific, Noumea (New Caledonia), pp. 145-154.

Srinivasan, M. S., and Kennett, J. P., 1981a. A review of Neogene planktonic foraminiferal biostratigraphy: Applications in the equatorial and South Pacific. In Warme, J. E., Douglas, R. G., Winter- er, E. L. (Eds.), The Deep Sea Drilling Project: A Decade of Progress. Soc. Econ. Paleontol. Mineral., Spec. Publ., 32:395-432.

, 1981b. Neogene planktonic foraminiferal biostratigraphy and evolution: Equatorial to sub-Antarctic, South Pacific. Mar. Micropaleontol., 6:499-533.

Date of Acceptance: 1 December 1983

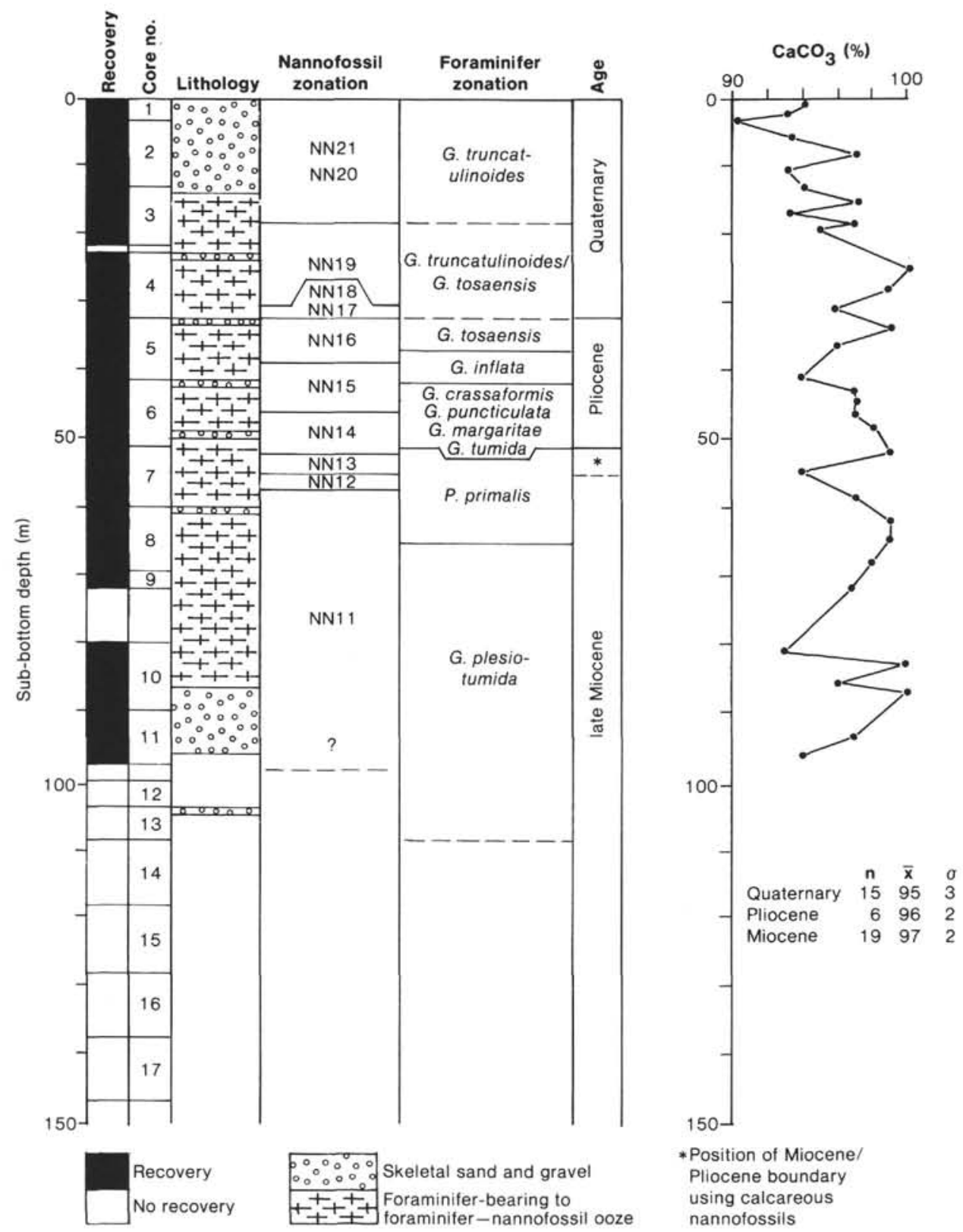

Figure 9. Summary lithology, biostratigraphy, and calcium carbonate percentages for Site 587. 


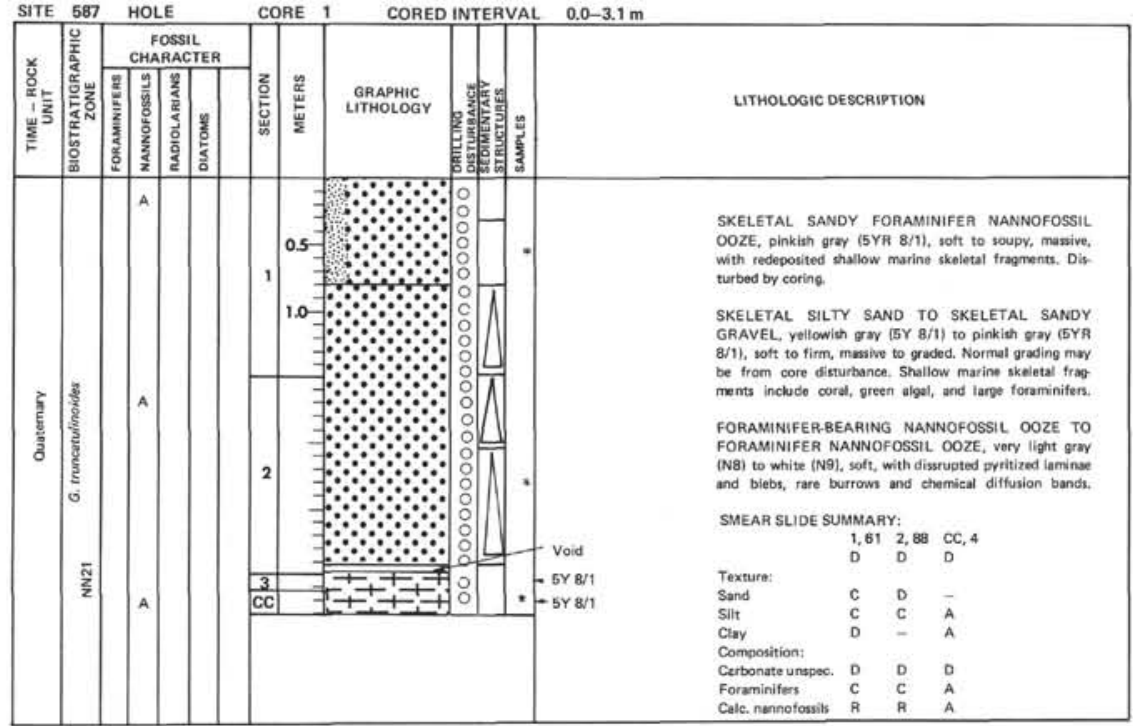

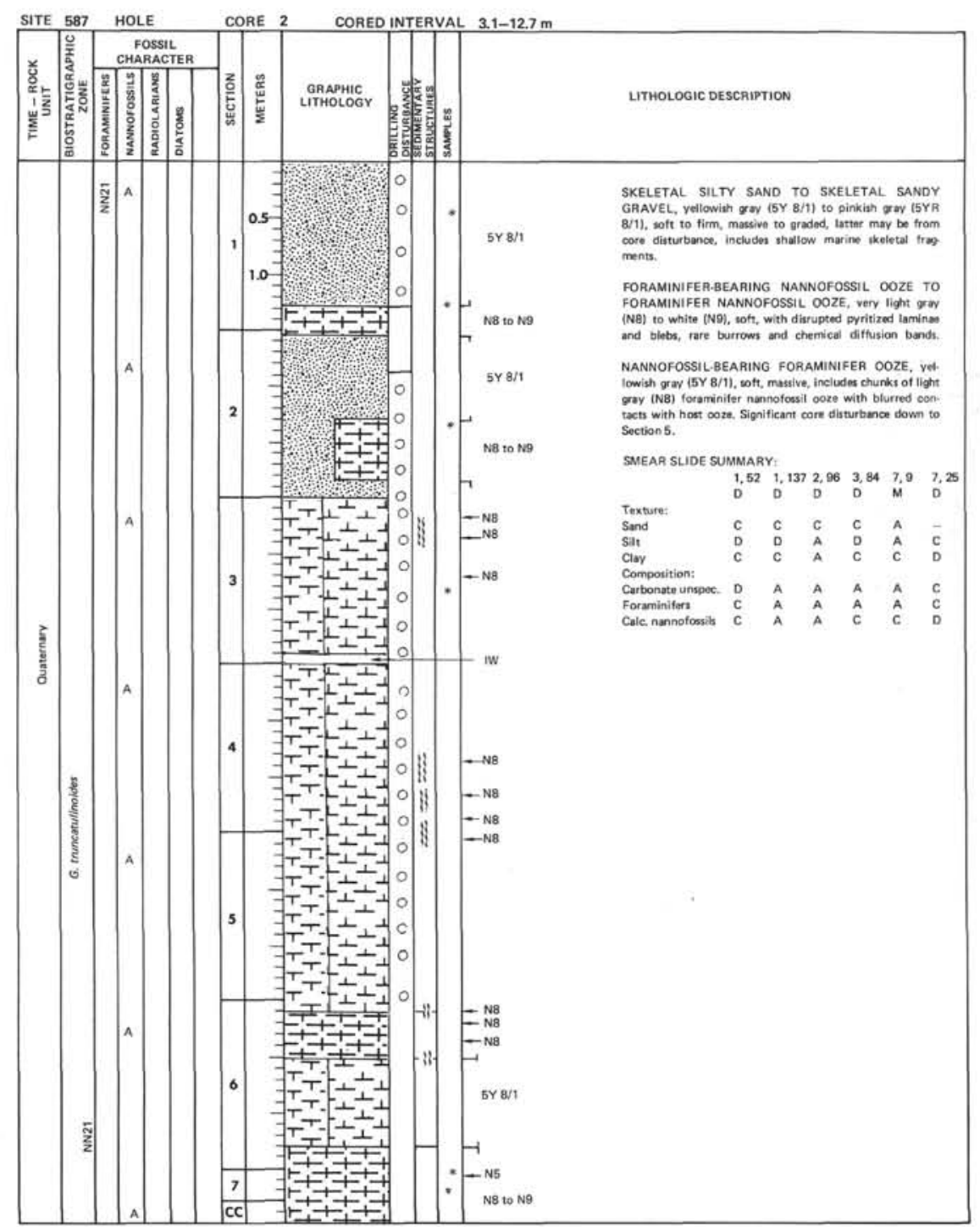



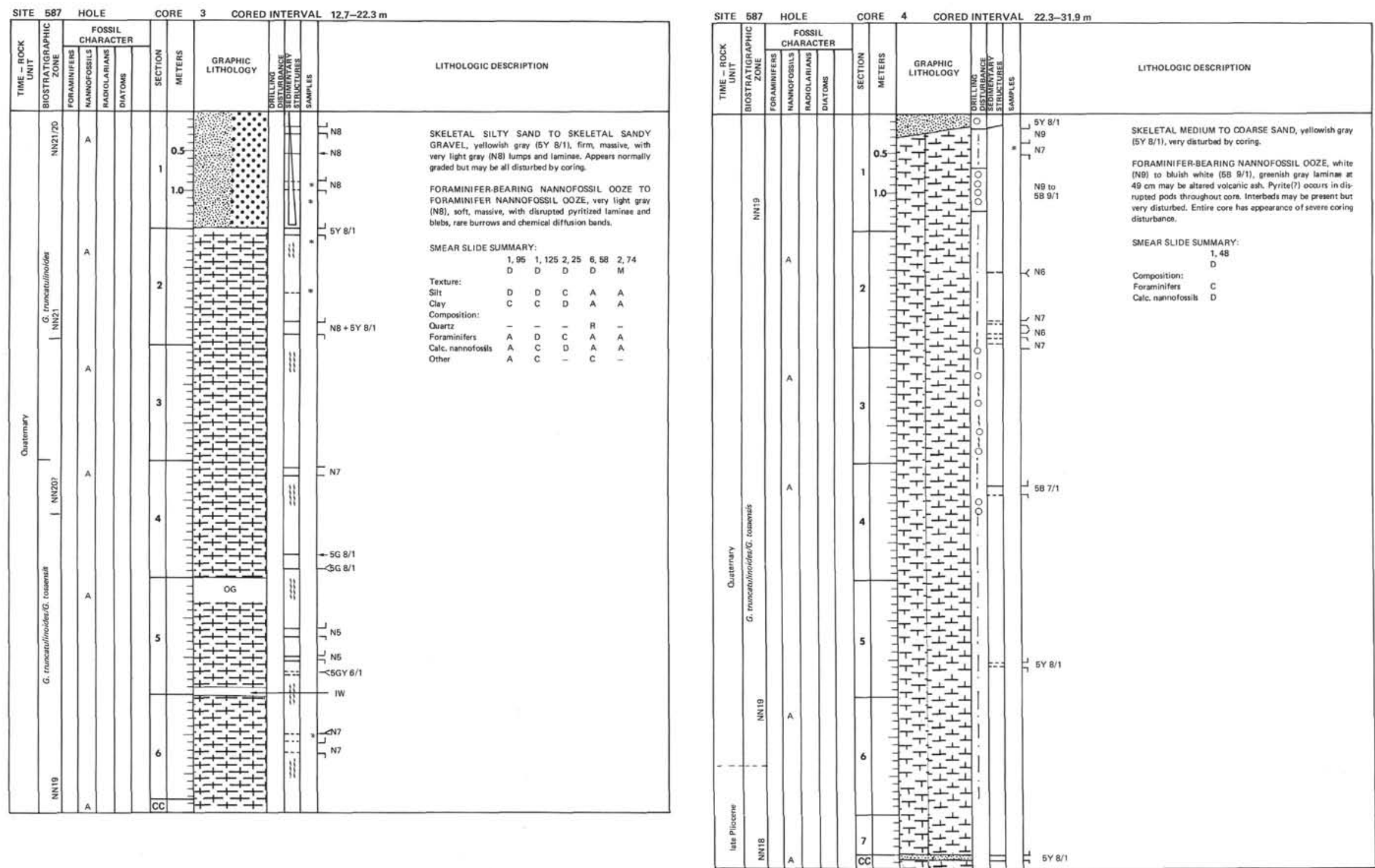

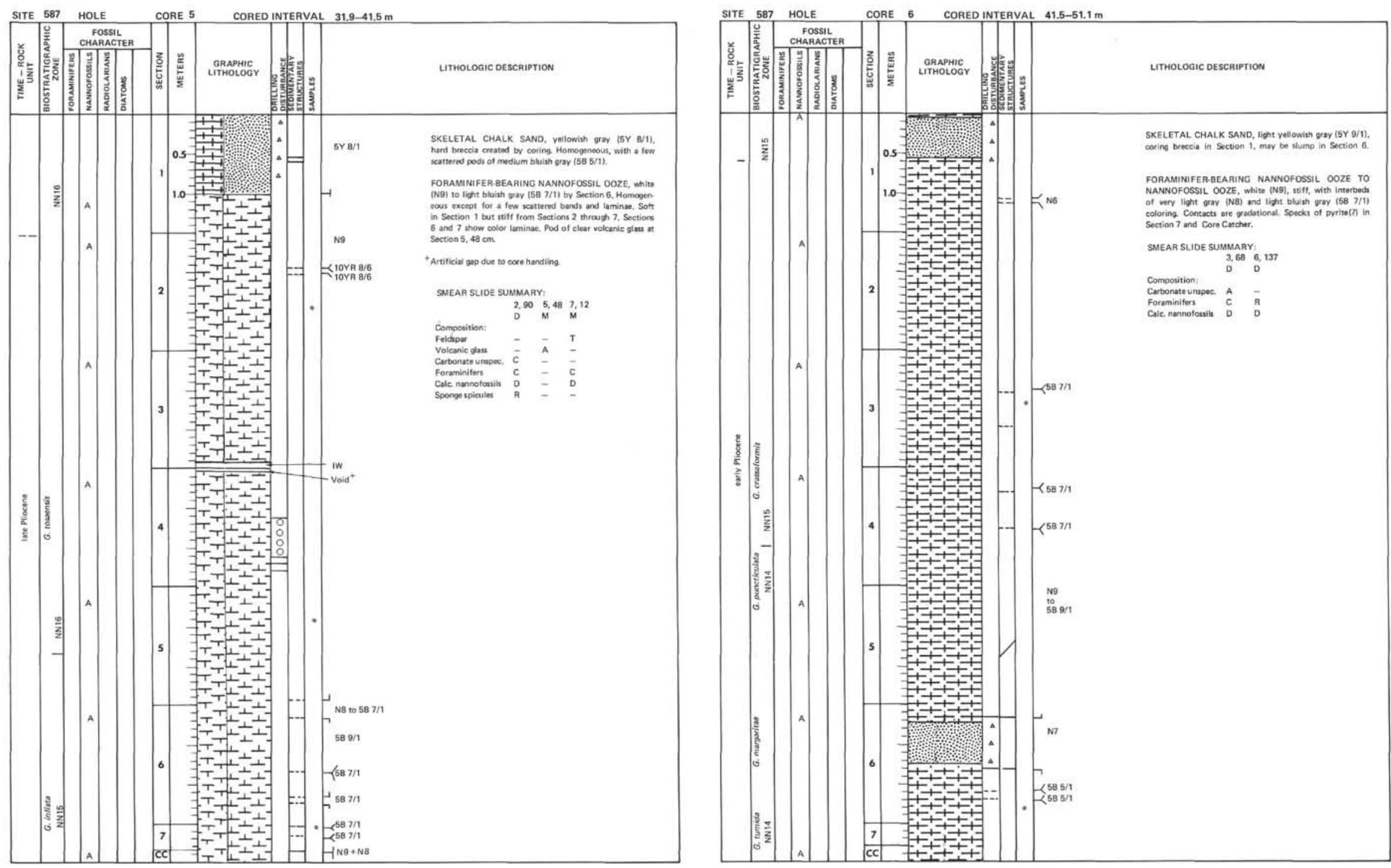

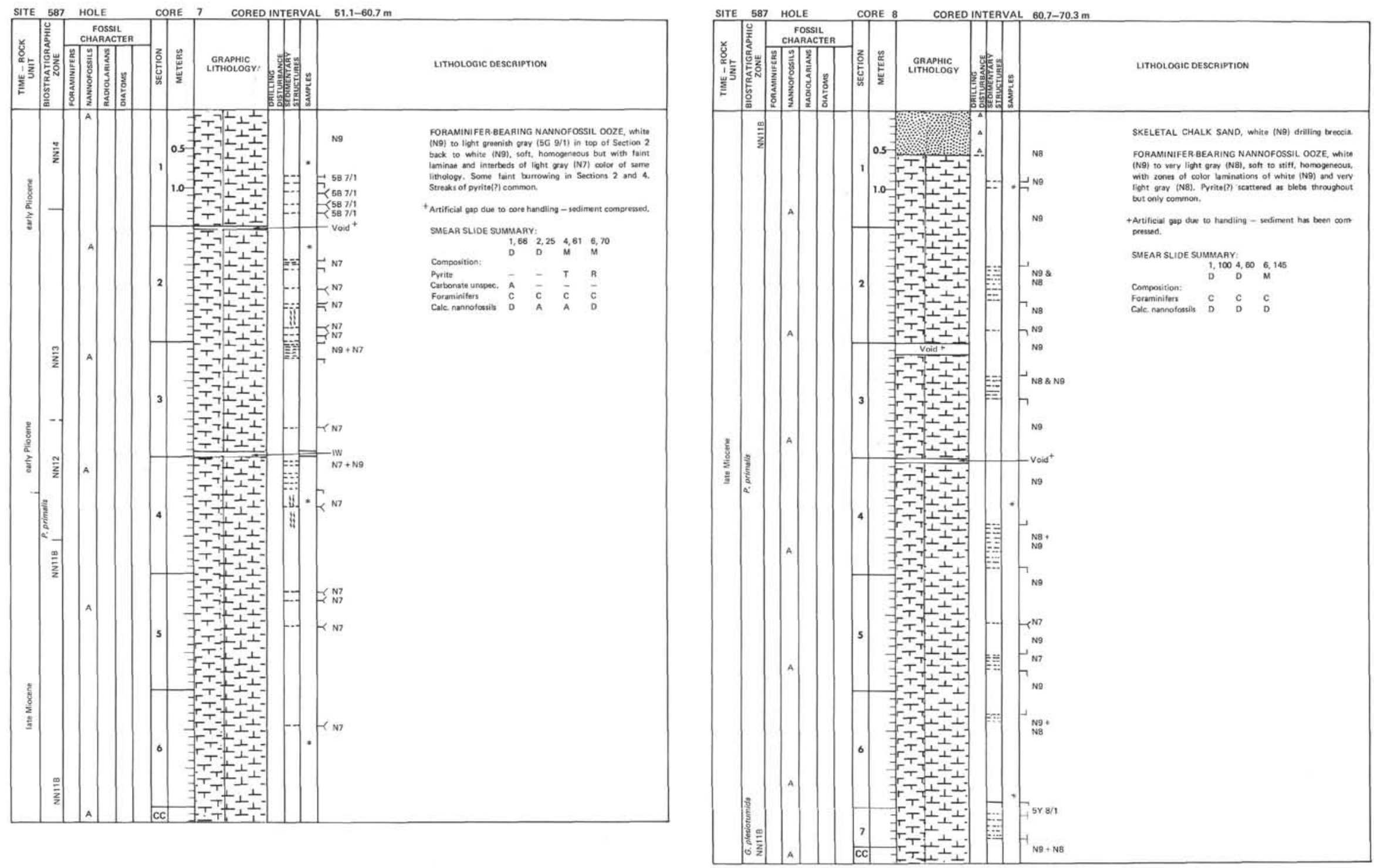

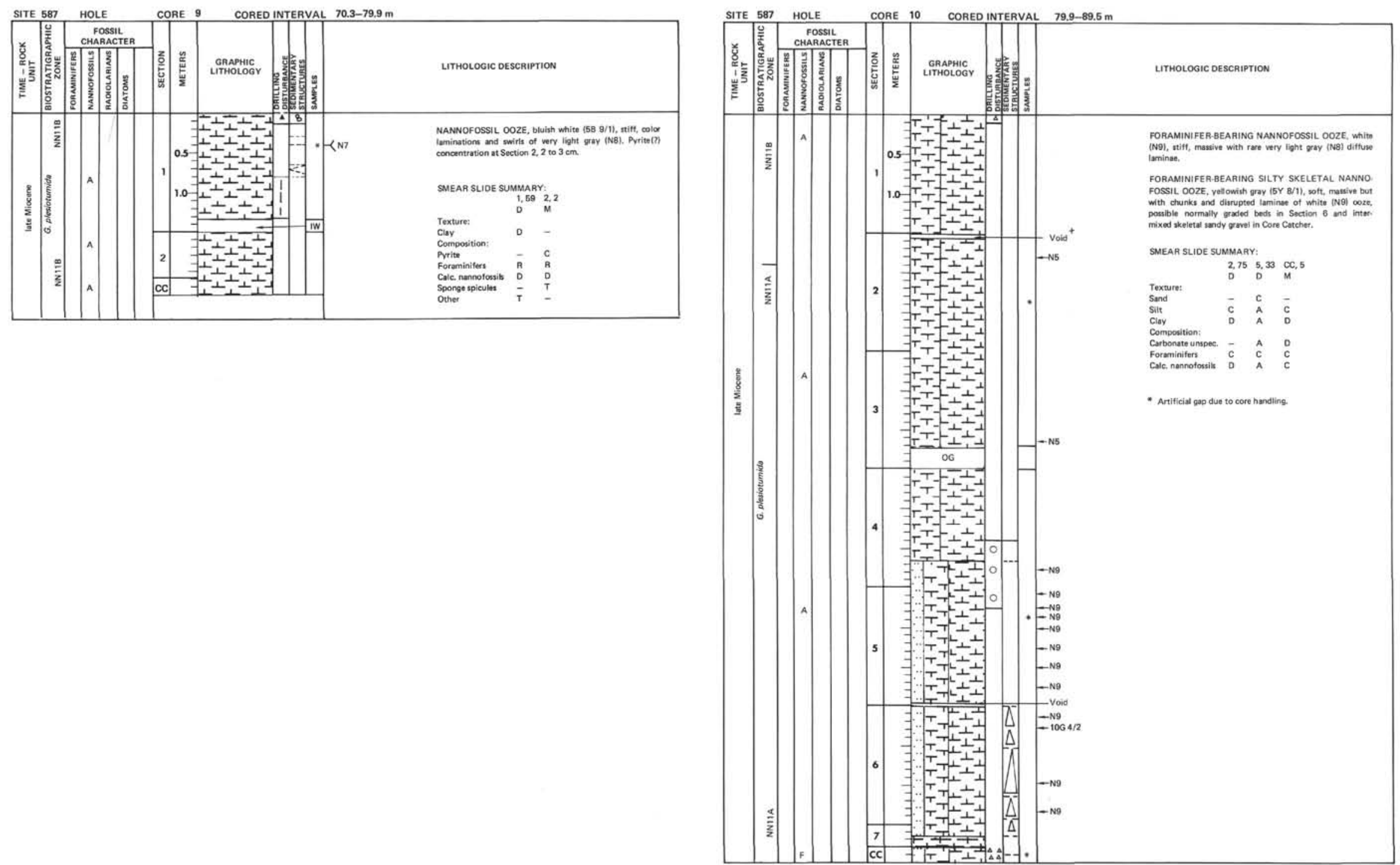

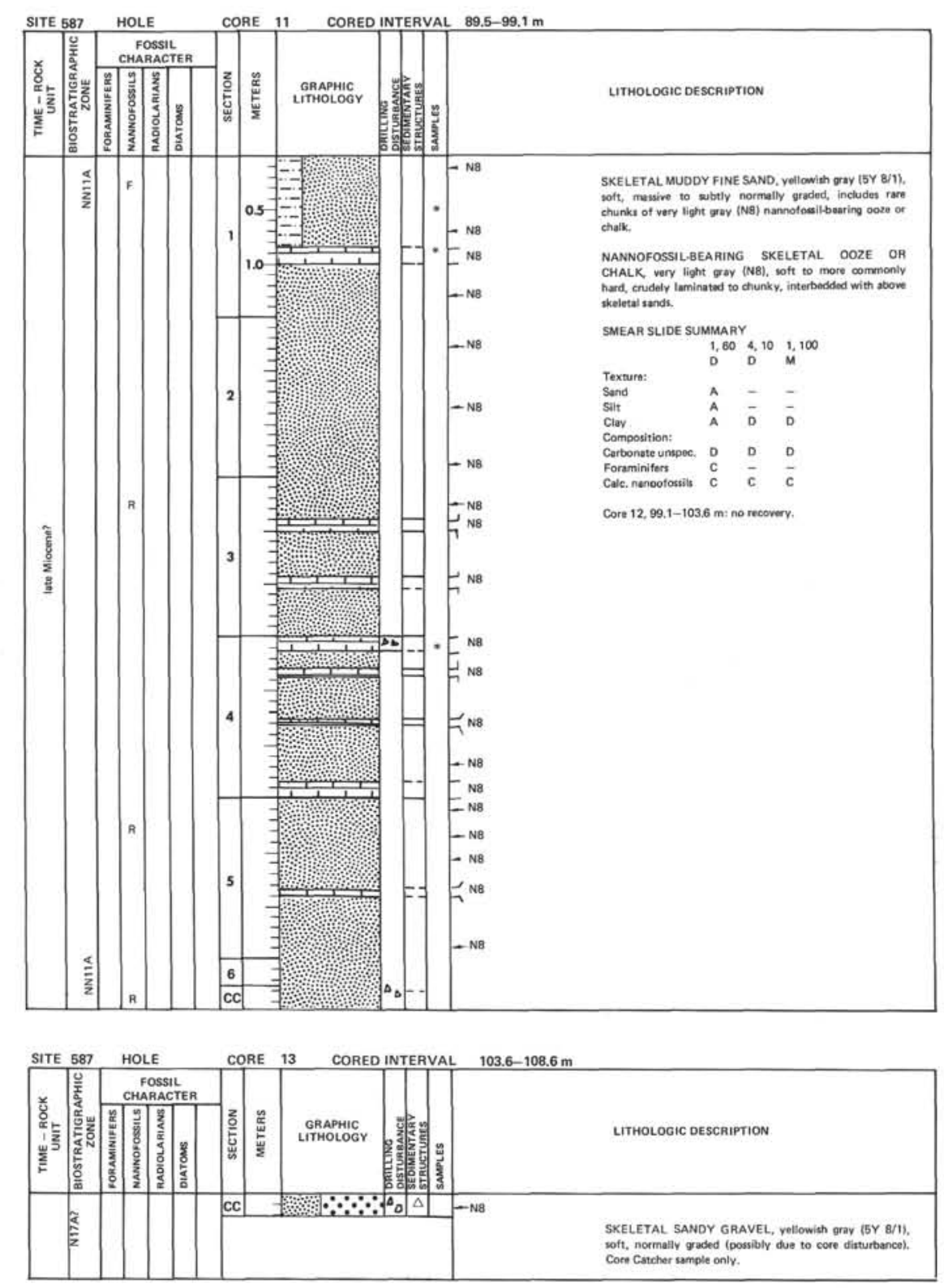


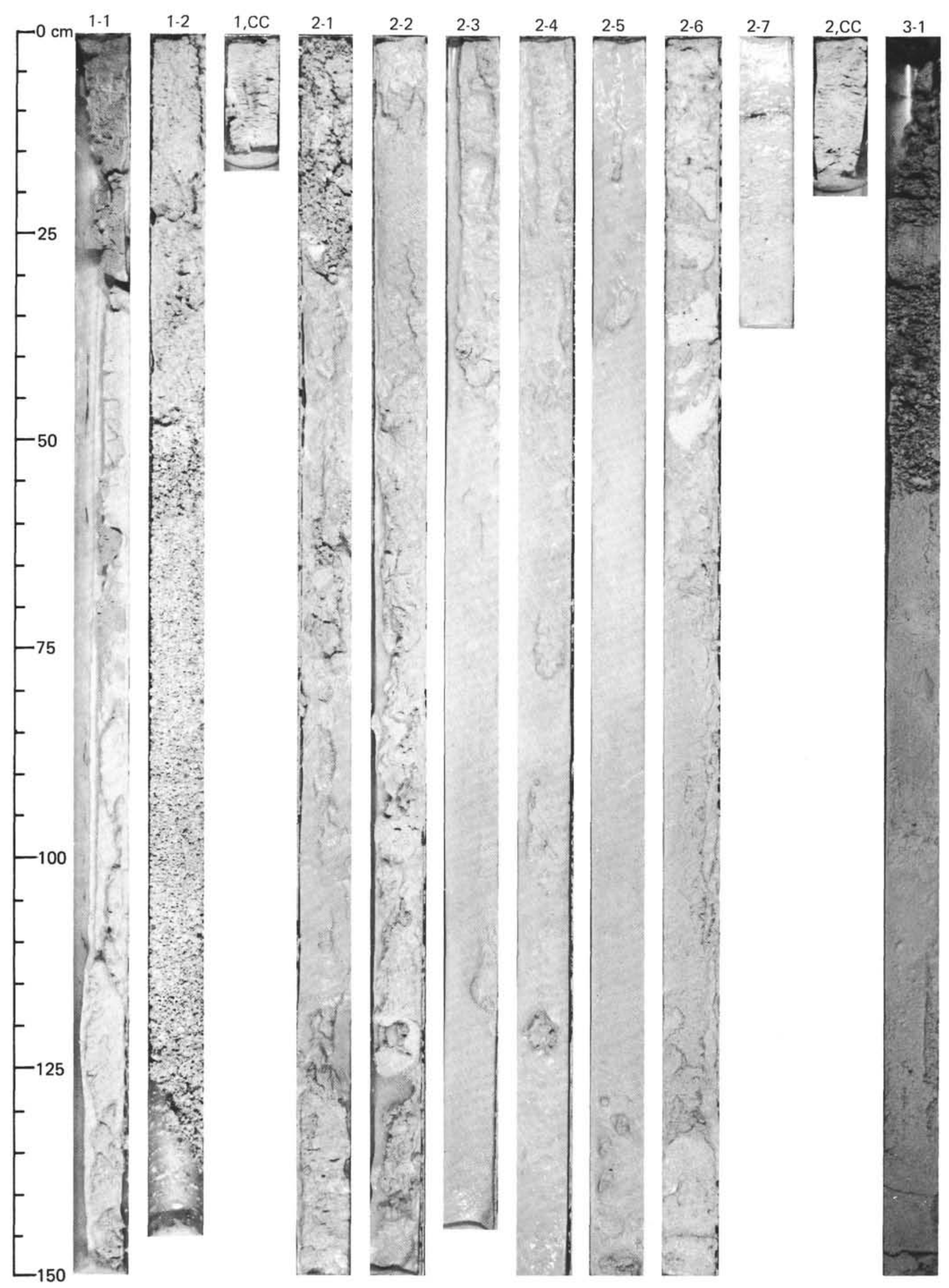




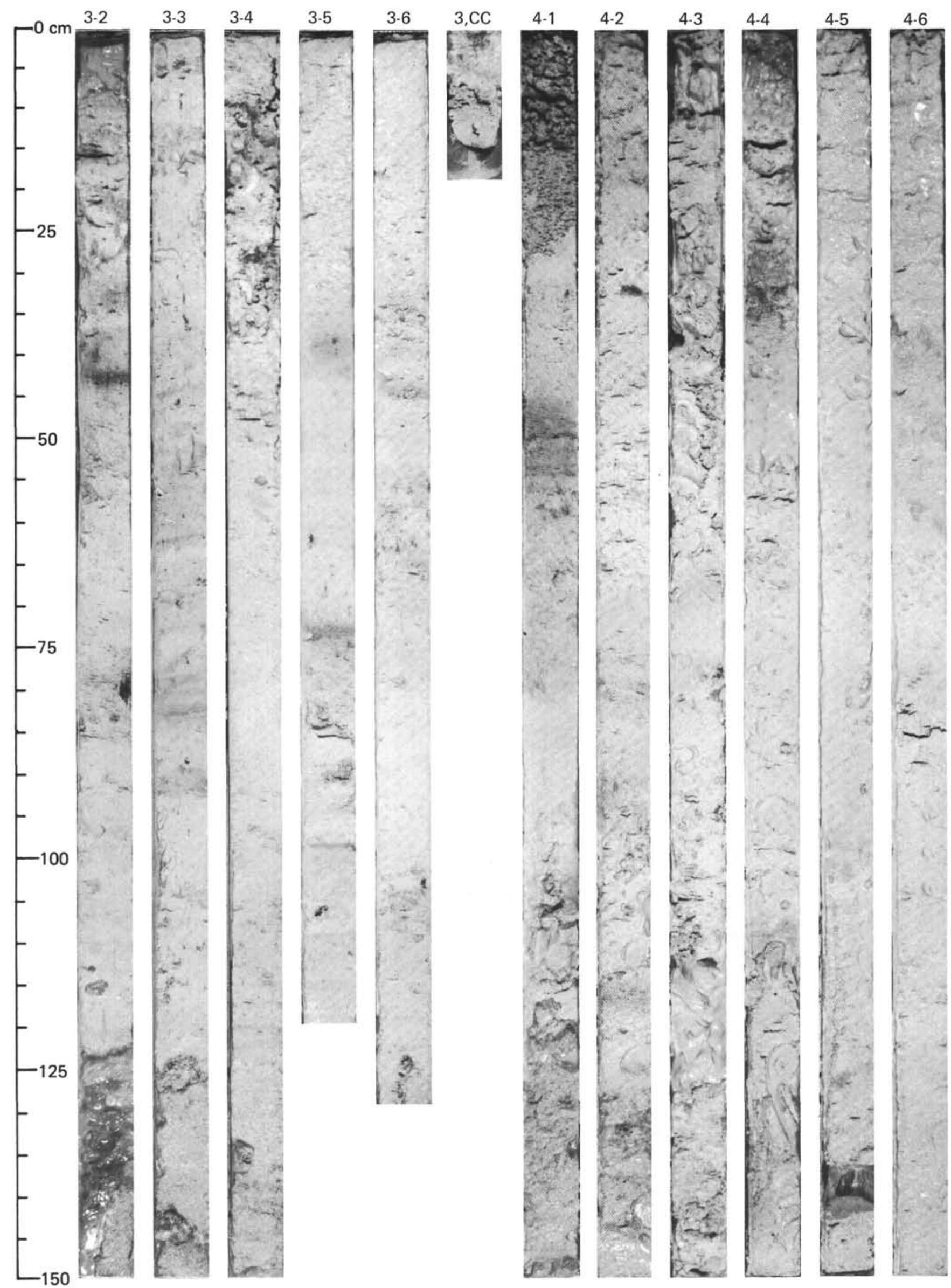


SITE 587

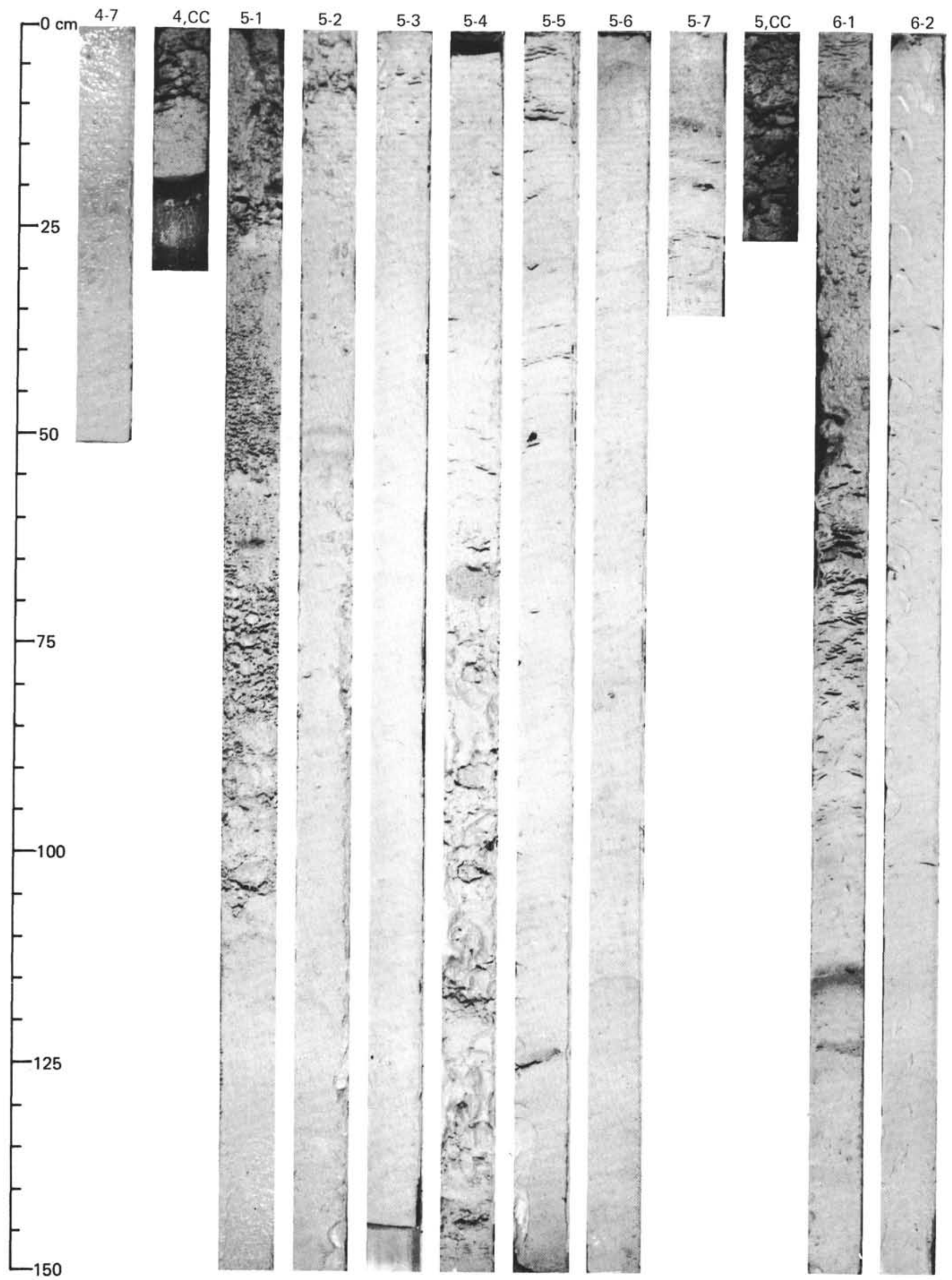




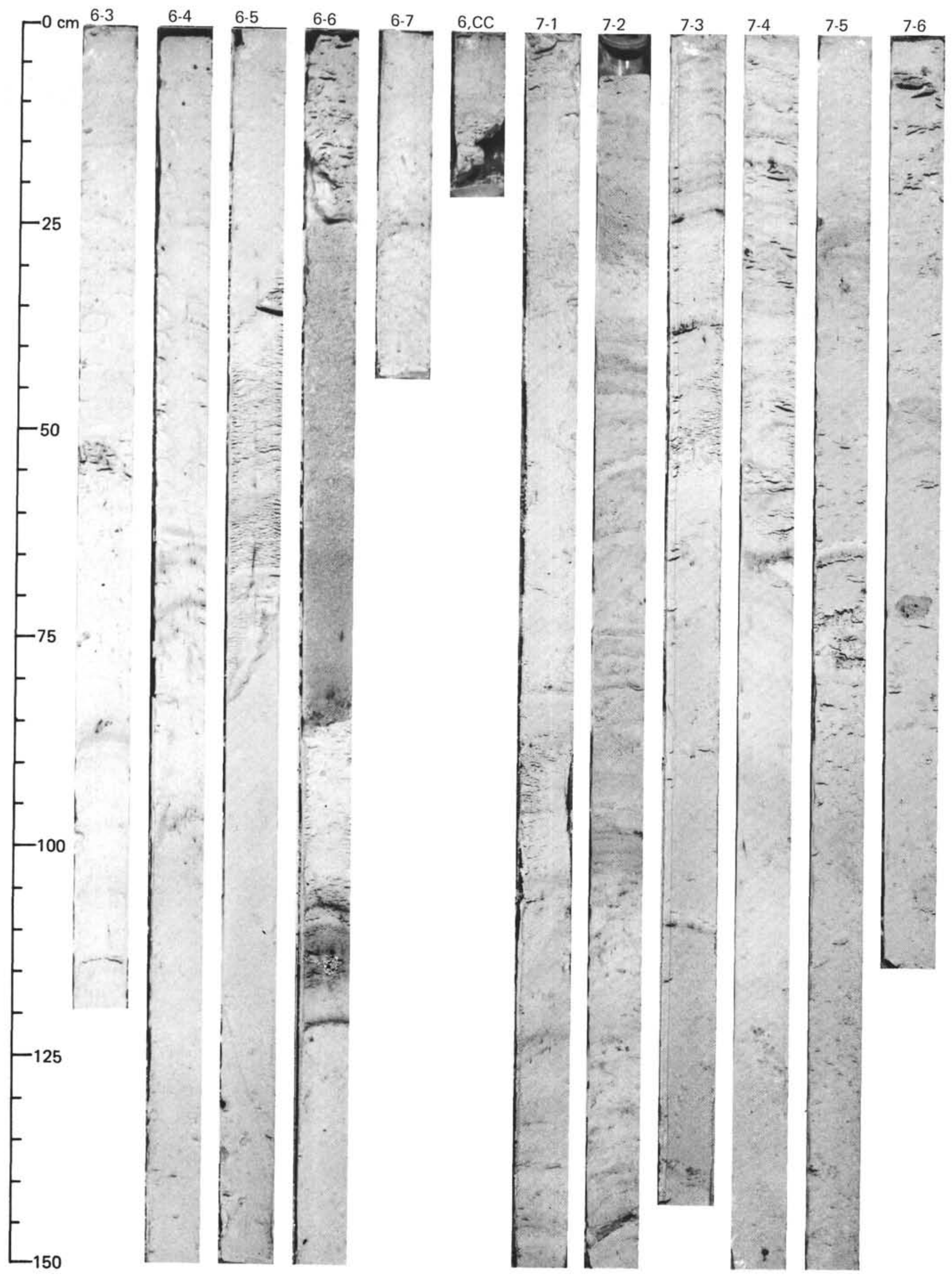




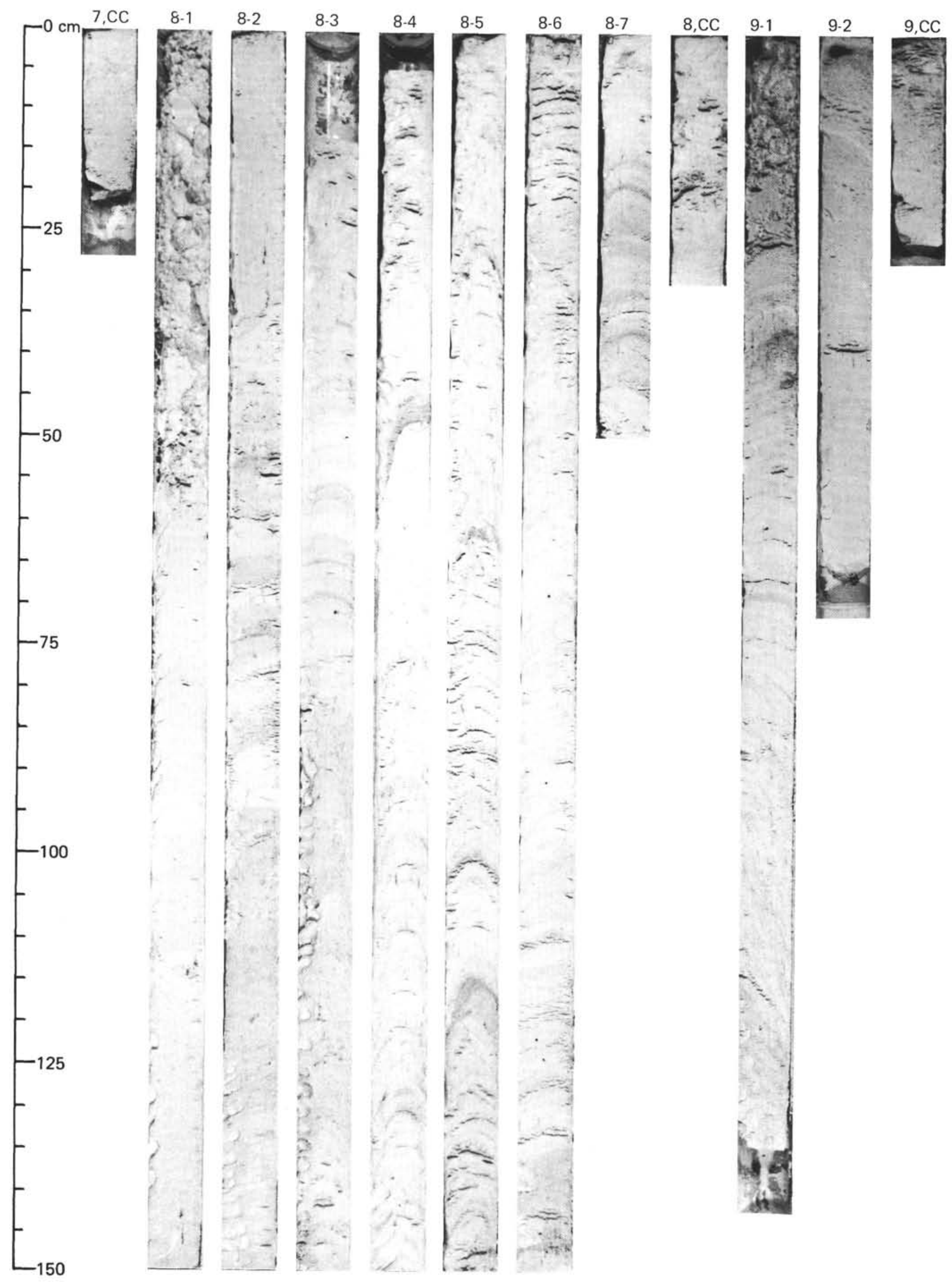




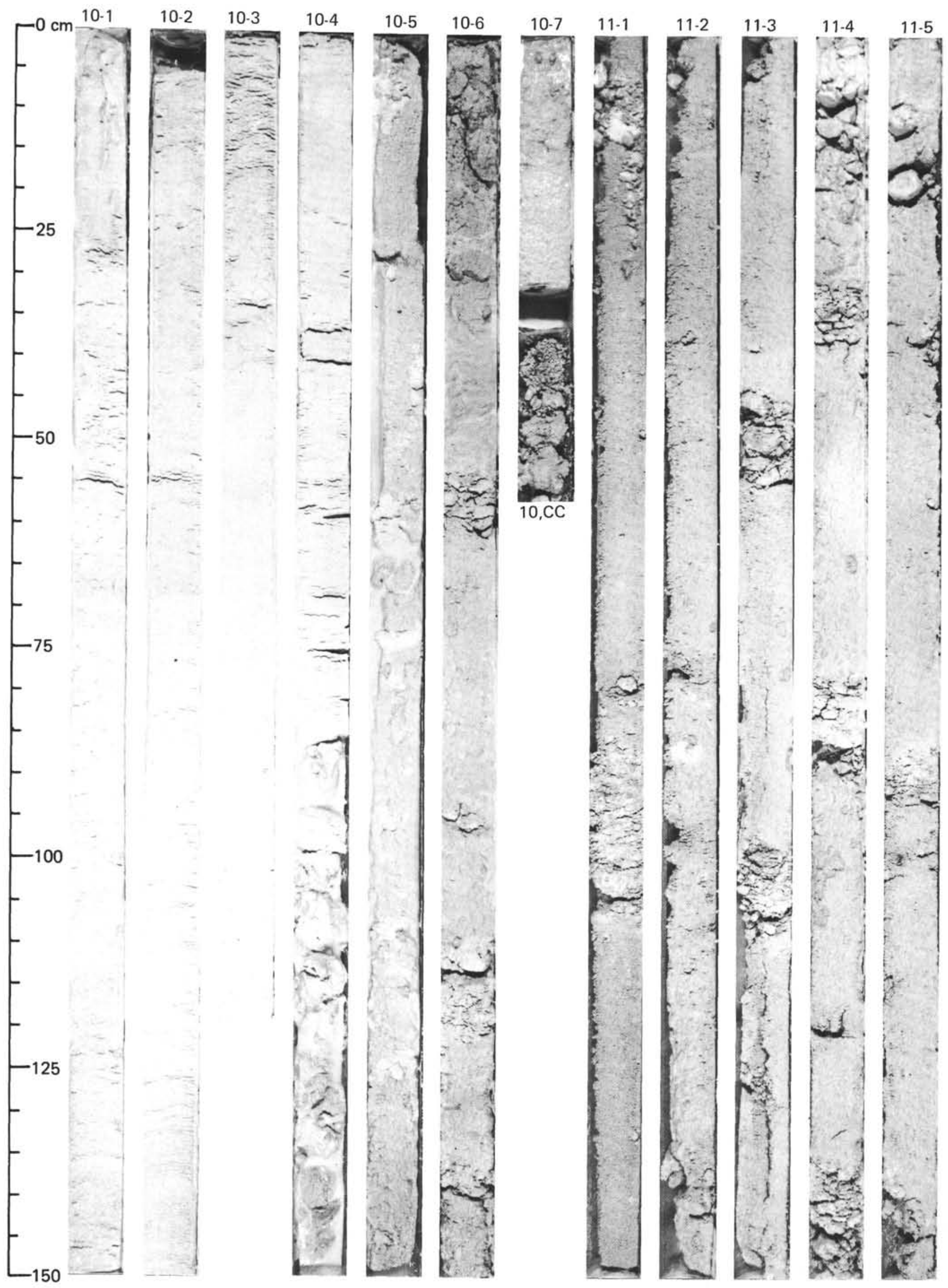


SITE 587

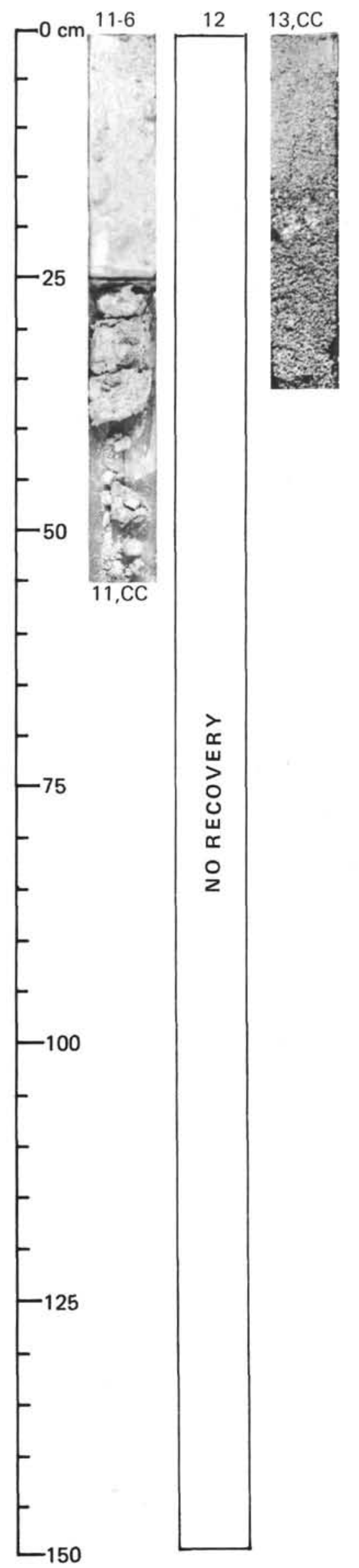

